\title{
Combining Ability and Mean Performance of Some New Inbred Lines of Yellow Maize Through Line $\times$ Tester Method Sultan, M. S. ${ }^{1}$; S. E. Sadek ${ }^{2}$; M. A. Abdel-Moneam ${ }^{1}$ and M. S. Shalof ${ }^{2}$ ${ }^{1}$ Agronomy Department, Faculty of Agriculture, Mansoura University, Egypt . \\ ${ }^{2}$ Maize Research Department, Field Croup Institute, Agriculture Research Center, Egypt .
}

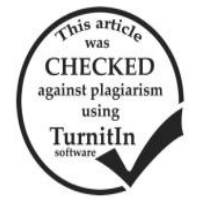

\section{ABSTRACT}

In Egypt, there are several maize production constraints, among which shortage of improved varieties is the major one. The objective of this study was to observe the mean performance of crosses and estimate combining abilities for grain yield and other agronomic traits in nine maize inbred lines and three testers using Line $\times$ Tester mating design. 27 yellow single crosses, 9 inbred lines , three testers and two standard checks (SC162 and SC168) were evaluated at two locations (Gemmeiza and Mallawy) under two density (24000 plant /fed and 30000 plant /fed). Analyses of variances showed significant mean squares for studied traits. Lines, tester and hybrids mean squares were highly significant and significant at combined data over two densities. Among the crosses, $\mathrm{P}_{1} \times \mathrm{Gm} 174, \mathrm{P}_{6}$ $\times \mathrm{Gm} 1021, \mathrm{P}_{7} \times \mathrm{Gm} 1021$ and $\mathrm{P}_{8} \times \mathrm{Gm} 1021$ highest grain yield mean performance and highly significant and significant in studied traits at combined data over both densities and these crosses may be useful for improving grain yield of maize. GCA effects, Inbred lines $\mathrm{P}_{6}, \mathrm{P}_{8}, \mathrm{P}_{2}, \mathrm{P}_{7}, \mathrm{Gm} 174$ and $\mathrm{Gm} 1021$ had significant and highly significant positive GCA effects and were the best general combiners for grain yield, and hence were promising parents for hybrids as well as for inclusion in breeding programs for yield improvement. Inbred line Gm 1021 could be considered as a good general combiner for earliness and parental inbred lines $\mathrm{P}_{1}, \mathrm{P}_{4}$ and $\mathrm{Gm} 1002$ could be considered as a good general combiners for lateness for day to $50 \%$ tasseling, indicating that the line Gm $1021 \mathrm{had}$ general combinations that can enhance early maturity. $\mathrm{P}_{1} \times \mathrm{Gm} 174, \mathrm{P}_{2} \times \mathrm{Gm} 1002, \mathrm{P}_{3} \times \mathrm{Gm} \mathrm{1002,} \mathrm{P}_{4} \times \mathrm{Gm} 174, \mathrm{P}_{5} \times \mathrm{Gm} 1021, \mathrm{P}_{6} \times \mathrm{Gm} 1021$, $\mathrm{P}_{7} \times \mathrm{Gm} 1002$ and $\mathrm{P}_{8} \times \mathrm{Gm} 1002$ had highly significant and significant positive SCA effects for grain yield trait. it could be concluded that the parental inbred line for that crosses could made themselves recombination's. The information of GCA and SCA effects for grain yield is very useful for maize breeders to determine which maize line should be selected to improve local lines and which parental lines should be used for making hybrids with greater grain yields.

Keywords: Maize, line $\times$ tester, general combining ability, specific combining ability.

Abbreviations: GCA general combining ability; SCA specific combining ability.

\section{INTRODUCTION}

Maize (Zea mays L.) is a diploid $(2 \mathrm{n}=20)$ crop and one of the oldest food grains in the world. It is a member of order Oales, family Poaceae, and sub family Panicoideae tribe maydeae. It is believed that the crop is originated. Maize is one of the most important strategic cereal crops in the world. It ranks third crop after wheat and rice in both terms of area and production in Egypt. The main objective of the maize breeding program in Egypt is to develop high yielding maize hybrids for commercial use to cover the increasing consumption of maize in human food, animal feeding and poultry industry. One of the most important criteria for identifying high yielding hybrids is the information about parents genetic structure and their combining ability (Ceyhan, 2003). The line $\times$ tester analysis method which suggested by Kempthorne (1957) is one of the powerful tools available to estimate general and specific combining ability effects and aids in selecting desirable parents and crosses. The effecteness of this method depends mainly upon the type of tester used in the evaluation. Nature and number of testers to be used in the line $\mathrm{x}$ tester model for evaluating inbred lines is still unsolved problem. The line $\times$ tester method using broad and narrow base testers is the most common procedure for the evaluating process. In this regard, the choice of a suitable tester is an important decision. There for, The obtained of this study highyielding parental lines and early ripening, as well as plant height and low ear and making optional vaccinations for high yield hybridization and early ripening

\section{MATERIALS AND METHODS}

The experimental work of this study was carried out during 2015 and 2016 summer season at two location (Gemmeiza and Mallawy Station) under two densities ( 24000 planets per fad. and 30000 planets per fad.) at the Agriculture Research Center (A.R.C.), Egypt. Nine yellow maize inbred lines, three testers Gm 174 ,Gm1002 and Gm1021, 27 yellow top single crosses and two yellow checks (single crosses 162 and 168) were planted by using Randomized Complete Block Design (R.C.B.D) with three replications was applied in two location ( Gemmeiza and
Mallawy) under two densities. Each replication contained 41 plots and each plot consisted of 1 row with $5 \mathrm{~m}$ long and spacing of $25 \mathrm{~cm}$ and $20 \mathrm{~cm}$ between plants within row and $70 \mathrm{~cm}$ between row ( Plot size was: $5 \mathrm{~m} \times 70 \mathrm{~cm}=$ $3.5 \mathrm{~m}^{2} /$ plot, no. of row in Fadden $=4200 / 3.5=1200$ row /plot and number of plant in Fadden $=1200 \times 20=24000$ plants / fadden and $1200 \times 25=30000$ plants / fadden). The data were recorded from five plants taken randomly from each row. data were recorded on the following characters on plot basis [ days to $50 \%$ tasseling, days to $50 \%$ silking , plant and ear height $(\mathrm{cm})$, ear position $(\%)$ and grain yield(ard./fed.)]. analysis of variance was performed for data collected from top crosses in each locations to test the significance of all genotypes. Homogeneity test revealed the validity of combined analysis of the two locations in the evaluation season for all the studied traits. All recorded data were examined according to analysis of variance procedures (ANOVA). The linear model utilized for individual analysis and least significant differences (LSD) at $5 \%$ and $1 \%$ significant level were calculated to evaluate the means. Line $\times$ tester analysis was performed according to (Kempthorne , 1957) to estimate the general and specific combining abilities and the interaction between line $x$ testers variances. Data were tested for normality by statistical software. Then, data were analyzed using Agrobase 21 (2001) and Microsoft excel. Analysis of traits from the lines, testers and crosses was conducted using the line by tester - AGR 21 procedure developed, according to method line by tester, which included the parents, direct and crosses. The LSD test at 5\% and $1 \%$ according to Steel and Torrie , (1980) was used for comparison the means of performance of the different genotypes .

For combined analyses

$\mathbf{X}_{\mathrm{lijk}}=\boldsymbol{\mu}+\mathbf{L}_{\mathrm{i}}+\mathbf{R}_{\mathrm{s}} / \mathbf{L}_{\mathrm{i}}+\mathbf{g}_{\mathrm{i}}+\mathbf{g}_{\mathrm{j}}+\mathrm{S}_{\mathrm{ij}}+\left(\mathbf{L g}_{\mathrm{i}}\right)_{\mathrm{ii}}+\left(\mathbf{L g}_{\mathrm{j}}\right)_{\mathrm{jj}}+\left(\mathbf{L S}_{\mathrm{ij}}\right)_{\mathrm{ijj}}+\ell_{\mathrm{isj}}$ $\mu=$ over all genotype mean

$\mathrm{L}_{\mathrm{i}}=$ locations effects.

$\mathrm{R}_{\mathrm{s}} / \mathrm{L}_{\mathrm{i}}=$ replications within locations effects.

$\mathrm{g}_{\mathrm{i}}=$ G.C.A. effect of the $\mathrm{i}$ the male parents (testers)

$\mathrm{g}_{\mathrm{j}}=$ G.C.A. effect of the $\mathrm{j}$ the female parents (inbred line)

$\mathrm{S}_{\mathrm{ij}}=$ S.C.A. effect of the $\mathrm{ij}$ the cross combinations.

$\left(\mathrm{Lg}_{\mathrm{i}}\right)_{\mathrm{li}}=$ interaction of location $\mathrm{x}$ males (testers) effects.

$\left(\mathrm{Lg}_{\mathrm{j}}\right)_{\mathrm{lj}}=$ interaction of location $\mathrm{x}$ female (inbred lines) effects. 
Sultan, M. S. et al.

$\left(\mathrm{LS}_{\mathrm{ij}}\right)_{\mathrm{ilj}}=$ interaction of between location, males and female $\ell$ effects.

$\ell_{\text {isij }}=$ the error associated with the each observation

Table 1. Names and the pedigree of the studied twelve yellow inbred lines.

\begin{tabular}{|c|c|c|c|}
\hline$\overline{\text { No. }}$ & Inbred line & Pedigree & Notes \\
\hline 1 & line 10 & EG-38-B5-2-77-1-1-1 & Line \\
\hline 2 & line 11 & EG-29-B5-2-57-2-1-1 & Line \\
\hline 3 & line 12 & Gm.Y.Pop.F14 & Line \\
\hline 4 & line 17 & EG-28-B5-2-131-2-3-1 & Line \\
\hline 5 & line 20 & EG-28-B5-2-127-1-1-1 & Line \\
\hline 6 & line 21 & Gm. y. Pop. F 21 & Line \\
\hline 7 & line 26 & EG-29-B5-2-186-1-1-1 & Line \\
\hline 8 & line 32 & Sc.2-F47-48/A2- 2003 & Line \\
\hline 9 & line 48 & EG-26-B5-1-49-1-1-1 & Line \\
\hline 10 & line $\mathrm{Gm} .174$ & EG-40-B5-2-104-2-1-1 & Tester \\
\hline 11 & line Gm.1002 & Sub trop._y. I.G. S. Pop._IITA_N.M.B.P. & Tester \\
\hline 12 & line Gm.1021 & IL. Sd-121 × Pop. (DMR- ESR) & Tester \\
\hline
\end{tabular}

al, N. M.B. P. F.C.R.I. A.R.C. , Egypt

\section{RESULTS AND DISCUSSION}

Analysis of variance

Mean squares were significant for all of the studied traits. Lines, testers and hybrids mean squares were highly significant and significant for the six traits over combined data under two densities except :

For silking date in crosses $\times$ loc., testers $\times$ loc and lines $\times$ testers $\times$ loc. in their combined data ; lines $\times$ loc. in $\mathrm{L}_{1} \mathrm{~L}_{2} \mathrm{D}_{2}, \mathrm{~L}_{1} \mathrm{D}_{1} \mathrm{D}_{2}$ and $\mathrm{L}_{2} \mathrm{D}_{1} \mathrm{D}_{2}$, rep $\times$ loc. in $\mathrm{L}_{1} \mathrm{D}_{1} \mathrm{D}_{2}$; crosses in $\mathrm{L}_{1} \mathrm{~L}_{2} \mathrm{D}_{2}$; lines in $\mathrm{L}_{1} \mathrm{~L}_{2} \mathrm{D}_{2}$ and lines $\times$ testers in $\mathrm{L}_{1} \mathrm{~L}_{2} \mathrm{D}_{2}$

For tasseling date in crosses $\times$ loc. and lines $\times$ testers $\times$ loc. in combined data, lines $\times$ loc. in $\mathrm{L}_{1} \mathrm{~L}_{2} \mathrm{D}_{2}$ and $\mathrm{L}_{1} \mathrm{D}_{1} \mathrm{D}_{2}$ ; testers $\times$ loc. in $\mathrm{L}_{1} \mathrm{~L}_{2} \mathrm{D}_{1}, \mathrm{~L}_{1} \mathrm{~L}_{2} \mathrm{D}_{2}$ and $\mathrm{L}_{1} \mathrm{D}_{1} \mathrm{D}_{2}$, crosses in $\mathrm{L}_{1} \mathrm{~L}_{2} \mathrm{D}_{2}$ and lines in $\mathrm{L}_{1} \mathrm{~L}_{2} \mathrm{D}_{2}$;

For grain yield had non-significant for rep. $\times$ loc. in $\mathrm{L}_{1} \mathrm{~L}_{2} \mathrm{D}_{1}, \mathrm{~L}_{1} \mathrm{~L}_{2} \mathrm{D}_{2}, \mathrm{~L}_{1} \mathrm{D}_{1} \mathrm{D}_{2}$ and $\mathrm{L}_{2} \mathrm{D}_{1} \mathrm{D}_{2}$. These results agree with those obtained by Sultan,el.al.,2010, Moosavi et.al.,2012 and Kamara, et.al.,2014.

Table 2. Mean squares of analysis of variance for days to50 \% tasseling and50 \% silking at combined over locations and over two densities.

\begin{tabular}{|c|c|c|c|c|c|c|c|c|c|}
\hline \multirow{2}{*}{ S.O.V. } & \multirow{2}{*}{$\begin{array}{c}\text { df } \\
\text { Comb }\end{array}$} & \multicolumn{4}{|c|}{ Days to50 \% tasseling } & \multicolumn{4}{|c|}{ Days to50 \% Silking } \\
\hline & & $\mathbf{L}_{1} \mathbf{L}_{2} \mathbf{D}_{1}$ & $\mathbf{L}_{1} \mathbf{L}_{2} \mathbf{D}_{2}$ & $\mathbf{L}_{1} \mathbf{D}_{1} \mathbf{D}_{2}$ & $\mathbf{L}_{2} \mathbf{D}_{1} \mathbf{D}_{2}$ & $\mathbf{L}_{1} \mathbf{L}_{2} \mathbf{D}_{1}$ & $\mathbf{L}_{1} \mathbf{L}_{2} \mathbf{D}_{2}$ & $\mathbf{L}_{1} \mathbf{D}_{1} \mathbf{D}_{2}$ & $\mathbf{L}_{2} \mathbf{D}_{1} \mathbf{D}_{2}$ \\
\hline Location & 1 & $9.20 * *$ & $162.50 * *$ & $38.60 * *$ & $6.17 *$ & $33.85 * *$ & $55.54 * *$ & $6.84 * *$ & $18.06 * *$ \\
\hline Rep. & 5 & $61.60 * *$ & $37.29 * *$ & $9.23 * *$ & $11.83 * *$ & $15.73 * *$ & $18.32 * *$ & 2.61 & $18.54 * *$ \\
\hline Rep. $\times$ Location & 4 & $9.15^{*}$ & $5.98 *$ & 1.90 & $13.25 * *$ & $11.20 * *$ & $9.01 * *$ & 1.55 & $18.66^{* *}$ \\
\hline Genotypes & 38 & $22.64 * *$ & $19.97 * *$ & $14.76^{* *}$ & $31.08 * *$ & $22.96 * *$ & $18.07 * *$ & $13.11 * *$ & $31.40 * *$ \\
\hline Parents & 11 & $19.10 * *$ & $11.92 * *$ & $10.07 * *$ & $28.07 * *$ & $19.97 * *$ & $11.33 * *$ & $8.87 * *$ & $28.58 * *$ \\
\hline Crosses & 26 & $7.06^{*}$ & 2.50 & $4.23 *$ & $5.76^{*}$ & $7.13 *$ & 2.13 & $3.63 *$ & $6.53 *$ \\
\hline Par. vs. crosses & 1 & $466.80 * *$ & $562.60 * *$ & $340.25 * *$ & $722.47 * *$ & $467.27 * *$ & $506.69 * *$ & $306.18 * *$ & $709.06 * *$ \\
\hline Lines & 8 & $4.72 *$ & 1.59 & 2.39 & $7.12 *$ & $3.92 *$ & 1.35 & $2.66^{*}$ & $6.74 * *$ \\
\hline Testers & 2 & $24.13 * *$ & $6.41 *$ & $15.90 * *$ & $11.88 * *$ & $24.03 * *$ & $9.64 * *$ & $18.38 * *$ & $14.27 * *$ \\
\hline Lines $\times$ testers & 16 & $6.09 *$ & 2.46 & 3.69 & $4.31 *$ & $6.62 *$ & 1.57 & 2.28 & $5.45 *$ \\
\hline crosses $\times$ location & 26 & 2.10 & 0.60 & 0.50 & 1.80 & 2.60 & 0.90 & 0.90 & 1.70 \\
\hline line $\times$ location & 8 & $4.70^{*}$ & 1.30 & 0.50 & 2.30 & $5.00 *$ & 1.80 & 0.60 & 2.10 \\
\hline tester $\times$ location & 2 & 0.00 & 0.70 & 1.10 & 2.40 & 0.50 & 0.80 & 0.60 & 1.70 \\
\hline line $\times$ tester $\times$ loc. & 16 & 1.10 & 0.20 & 0.40 & 1.50 & 1.70 & 0.50 & 1.00 & 1.60 \\
\hline par $\times$ loc & 11 & $8.43 * *$ & $4.06^{*}$ & 2.68 & 2.68 & $5.89 *$ & $4.62 *$ & 1.98 & 2.37 \\
\hline p.vs. cr. $\times$ location & 1 & $64.13 * *$ & 0.18 & $23.51 * *$ & $7.48^{*}$ & $45.04 * *$ & $5.85 *$ & $6.72 *$ & 2.89 \\
\hline Error & 152 & 2.87 & 1.51 & 1.83 & 1.83 & 2.69 & 1.65 & 1.74 & 1.89 \\
\hline
\end{tabular}

$*$ *** significant at 0.05 and 0.01 level of probability , respectively

Abbreviations: $L_{1}$ location Gemmeiza ; $L_{2}$ location Mallawy; $D_{1}$ density one (30000 plant / fed.) and $D_{2}$ density two (24000 plant / fed.).

Table 3. Mean squares of analysis of variance for plant height and ear height at combined data over locations and over two densities.

\begin{tabular}{|c|c|c|c|c|c|c|c|c|c|}
\hline \multirow{2}{*}{ S.O.V. } & \multirow{2}{*}{$\begin{array}{c}\text { df } \\
\text { Comb }\end{array}$} & \multicolumn{4}{|c|}{ Plant height (cm) } & \multicolumn{4}{|c|}{ Ear height $(\mathrm{cm})$} \\
\hline & & $\mathbf{L}_{1} \mathbf{L}_{2} \mathbf{D}_{1}$ & $\mathbf{L}_{1} \mathbf{L}_{2} \mathbf{D}_{2}$ & $\mathbf{L}_{1} \mathbf{D}_{1} \mathbf{D}_{2}$ & $\mathbf{L}_{2} \mathbf{D}_{1} \mathbf{D}_{2}$ & $\mathbf{L}_{1} \mathbf{L}_{2} \mathbf{D}_{1}$ & $\mathbf{L}_{1} \mathbf{L}_{2} \mathbf{D}_{2}$ & $\mathbf{L}_{1} \mathbf{D}_{1} \mathbf{D}_{2}$ & $\mathbf{L}_{2} \mathbf{D}_{1} \mathbf{D}_{2}$ \\
\hline Location & 1 & $12701.6^{* *}$ & $23280.1^{* *}$ & $12701.6^{* *}$ & $23280.1 * *$ & $12701.6^{* *}$ & $23280.1 * *$ & $12701.6^{* *}$ & $23280.1^{* *}$ \\
\hline Rep. & 5 & $2548.97 * *$ & $5143.83 * *$ & $2548.97 * *$ & $5143.83 * *$ & $2548.97 * *$ & $5143.83 * *$ & $2548.97 * *$ & $5143.83 * *$ \\
\hline Rep. $\times$ Location & 4 & $10.80 * *$ & $609.75 * *$ & $10.80 * *$ & $609.75 * *$ & $10.80 * *$ & $609.75 * *$ & $10.80 * *$ & $609.75 * *$ \\
\hline Genotypes & 38 & $3719.08 * *$ & 7237.50 ** & $3719.08 * *$ & $7237.50 * *$ & $3719.08 * *$ & $7237.50 * *$ & $3719.08 * *$ & 7237.50 ** \\
\hline Parents & 11 & $581.41 * *$ & $634.14 * *$ & $581.41 * *$ & $634.14^{* *}$ & $581.41 * *$ & $634.14 * *$ & $581.41 * *$ & $634.14 * *$ \\
\hline Crosses & 26 & $212.11 * *$ & $412.75 * *$ & $212.11 * *$ & $412.75^{* *}$ & $212.11 * *$ & $412.75 * *$ & $212.11 * *$ & $412.75 * *$ \\
\hline Par. vs & 1 & $129414.6 * *$ & $257318.1 * *$ & $129414.6^{* *}$ & $257318.1 * *$ & $129414.6^{* *}$ & $257318.1 * *$ & $129414.6^{* *}$ & $257318.1 * *$ \\
\hline Lines & 8 & $171.07 * *$ & $537.26^{* *}$ & $171.07 * *$ & $537.26^{* *}$ & $171.07 * *$ & $537.26^{* *}$ & $171.07 * *$ & $537.26 * *$ \\
\hline Testers & 2 & $238.35^{* *}$ & $133.90 * *$ & $238.35^{* *}$ & $133.90^{* *}$ & $238.35^{* *}$ & $133.90 * *$ & $238.35^{* *}$ & $133.90 * *$ \\
\hline Lines $\times$ testers & 16 & $229.35 * *$ & $385.35 * *$ & $229.35 * *$ & $385.35 * *$ & $229.35 * *$ & $385.35 * *$ & $229.35 * *$ & $385.35 * *$ \\
\hline crosses $\times$ location & 26 & $202.30 * *$ & $336.50 * *$ & $202.30 * *$ & $336.50 * *$ & $202.30 * *$ & $336.50 * *$ & $202.30 * *$ & $336.50 * *$ \\
\hline line $\times$ location & 8 & $140.40 * *$ & $265.10 * *$ & $140.40 * *$ & $265.10 * *$ & $140.40 * *$ & $265.10 * *$ & $140.40 * *$ & $265.10 * *$ \\
\hline tester $\times$ location & 2 & $134.60 * *$ & $335.00 * *$ & $134.60 * *$ & $335.00 * *$ & $134.60 * *$ & $335.00 * *$ & $134.60 * *$ & $335.00 * *$ \\
\hline line $\times$ tester $\times$ loc. & 16 & $241.70 * *$ & $372.30 * *$ & $241.70 * *$ & $372.30 * *$ & $241.70 * *$ & $372.30 * *$ & $241.70 * *$ & $372.30 * *$ \\
\hline par $\times$ loc & 11 & $360.53 * *$ & $381.83 * *$ & $360.53 * *$ & $381.83 * *$ & $360.53 * *$ & $381.83 * *$ & $360.53 * *$ & $381.83 * *$ \\
\hline p.vs. cr. $\times$ location & 1 & $210.62 * *$ & $21692.3^{* *}$ & $210.62 * *$ & $21692.3^{* *}$ & $210.62 * *$ & $21692.3 * *$ & $210.62 * *$ & $21692.3^{* *}$ \\
\hline Error & 152 & 84.35 & 262.76 & 84.35 & 262.76 & 84.35 & 262.76 & 84.35 & 262.76 \\
\hline
\end{tabular}


Table 4. Mean squares of analysis of variance for ear position and grain yield at combined data over locations and over two densities.

\begin{tabular}{|c|c|c|c|c|c|c|c|c|c|}
\hline \multirow{2}{*}{ S.O.V. } & \multirow{2}{*}{$\begin{array}{c}\text { df } \\
\text { Comb }\end{array}$} & \multicolumn{4}{|c|}{ Ear position (\%) } & \multicolumn{4}{|c|}{ Grain yield (ard./fed.) } \\
\hline & & $\mathbf{L}_{1} \mathbf{L}_{2} \mathbf{D}_{1}$ & $\mathbf{L}_{1} \mathbf{L}_{2} \mathbf{D}_{2}$ & $\mathbf{L}_{1} \mathbf{D}_{1} \mathbf{D}_{2}$ & $\mathbf{L}_{2} \mathbf{D}_{1} \mathbf{D}_{2}$ & $\mathbf{L}_{1} \mathbf{L}_{2} \mathbf{D}_{1}$ & $\mathbf{L}_{1} \mathbf{L}_{2} \mathbf{D}_{2}$ & $\mathbf{L}_{1} \mathbf{D}_{1} \mathbf{D}_{2}$ & $\mathbf{L}_{2} \mathbf{D}_{1} \mathbf{D}_{2}$ \\
\hline Location & 1 & $156.97^{* *}$ & $380.63^{* *}$ & $37.38^{* *}$ & 0.75 & $110.83^{* *}$ & $310.29^{* *}$ & $357.17 * *$ & 139.50 ** \\
\hline Rep. & 5 & $38.10 * *$ & $113.66^{* *}$ & $15.60 * *$ & $36.31 * *$ & $24.72 * *$ & $67.59 * *$ & $75.26 * *$ & $32.11 * *$ \\
\hline Rep. $\times$ Location & 4 & $8.41^{* *}$ & $46.92 * *$ & $10.15^{* *}$ & $45.17^{* *}$ & 3.20 & $6.93 *$ & 4.82 & 5.30 \\
\hline Genotypes & 38 & $18.79 * *$ & $30.91 * *$ & $39.00 * *$ & $18.06^{* *}$ & $689.47 * *$ & $755.08 * *$ & $790.06^{* *}$ & $652.14 * *$ \\
\hline Parents & 11 & $39.78 * *$ & $50.89^{* *}$ & $78.23 * *$ & $37.80 * *$ & $46.94 * *$ & $31.89 * *$ & $56.51 * *$ & $31.15^{* *}$ \\
\hline Crosses & 26 & $10.18 * *$ & $13.78 * *$ & $23.75 * *$ & $6.08 *$ & $66.09 * *$ & $49.47 * *$ & $75.70 * *$ & $31.73 * *$ \\
\hline Par. vs. crosses & 1 & $11.43 * *$ & $256.34 * *$ & $4.09 *$ & $112.55 * *$ & $23965.5 * *$ & $27056.0 * *$ & $27432.6^{* *}$ & $23613.5^{* *}$ \\
\hline Lines & 8 & $5.88 *$ & $10.75 * *$ & $22.33 * *$ & $6.30 *$ & $56.04 * *$ & $25.38 * *$ & $64.30 * *$ & $30.08 * *$ \\
\hline Testers & 2 & $9.62 * *$ & $29.49 * *$ & $37.07 * *$ & 2.02 & $165.89 * *$ & $124.85^{* *}$ & $238.13^{* *}$ & $90.92 * *$ \\
\hline Lines $\times$ testers & 16 & $12.41 * *$ & $13.34 * *$ & $22.79 * *$ & $6.48 *$ & $58.63 * *$ & $52.08 * *$ & $61.09 * *$ & $25.16^{* *}$ \\
\hline crosses $\times$ location & 26 & $11.10^{* *}$ & $12.20 * *$ & $13.00 * *$ & $4.40 *$ & $24.00 * *$ & $19.30 * *$ & $27.70 * *$ & $23.70 * *$ \\
\hline line $\times$ location & 8 & $11.30 * *$ & $14.60 * *$ & $11.90 * *$ & 2.00 & $41.90 * *$ & $21.60 * *$ & $21.30 * *$ & $29.30 * *$ \\
\hline tester $\times$ location & 2 & $7.20 *$ & $14.30 * *$ & $12.40 * *$ & $9.10^{* *}$ & $18.80^{* *}$ & $46.20 * *$ & $24.30 * *$ & 2.40 \\
\hline line $\times$ tester $\times$ loc. & 16 & $11.40 * *$ & $10.70 * *$ & $13.70 * *$ & $5.00 *$ & $15.70 * *$ & $14.80 * *$ & $31.30 * *$ & $23.60 * *$ \\
\hline par $\times$ loc & 11 & $40.56^{* *}$ & $23.37 * *$ & $14.86^{* *}$ & $23.72 * *$ & $23.79 * *$ & $12.64 * *$ & $17.61 * *$ & $9.98 *$ \\
\hline p.vs. cr. $\times$ location & 1 & $225.42 * *$ & $557.22 * *$ & $92.38 * *$ & $841.46 * *$ & $11.42 * *$ & $73.58 * *$ & $55.35 * *$ & 5.02 \\
\hline Error & 152 & 9.29 & 15.31 & 6.68 & 16.44 & 7.38 & 6.31 & 7.99 & 6.17 \\
\hline
\end{tabular}

*, ** significant at 0.05 and 0.01 level of probability , respectively

Abbreviations: $L_{1}$ location Gemmeiza ; $L_{2}$ location Mallawy; $D_{1}$ density one (30000 plant / fed.) and $D_{2}$ density two (24000 plant / fed.).

\section{Mean Performance}

The mean performance of 9 lines , 3 testers and 27 top crosses for all the studied traits at their combined data over two densities are shown in Tables 5 - 8 .

Means of days to $50 \%$ tasseling are presented in Table (5). The differences between number of days to $50 \%$ tasseling for lines and testers were highly significant at combined data over two densities. Number of days from sowing to $50 \%$ tasseling were ranged from 54.83 to 60.83 days in $\mathrm{L}_{1} \mathrm{~L}_{2} \mathrm{D}_{1}, 55.17$ to 59.67 days in $\mathrm{L}_{1} \mathrm{~L}_{2} \mathrm{D}_{2}, 56.50$ to 60.50 days in $\mathrm{L}_{1} \mathrm{D}_{1} \mathrm{D}_{2}$, and 53 to 60.33 days in $\mathrm{L}_{2} \mathrm{D}_{1} \mathrm{D}_{2}$. The earliest line in $50 \%$ tasseling was $\mathrm{P}_{1}$ (line 10) in $\mathrm{L}_{1} \mathrm{~L}_{2} \mathrm{D}_{1}$ , $\mathrm{L}_{1} \mathrm{~L}_{2} \mathrm{D}_{2}, \mathrm{~L}_{2} \mathrm{D}_{1} \mathrm{D}_{2}$. Meanwhile, $\mathrm{P}_{9}$ (line 48) in $\mathrm{L}_{1} \mathrm{~L}_{2} \mathrm{D}_{2}$, $\mathrm{L}_{2} \mathrm{D}_{1} \mathrm{D}_{2}$ and $\mathrm{P}_{7}$ (line 26) in $\mathrm{L}_{1} \mathrm{~L}_{2} \mathrm{D}_{1}$ were the latest lines at combined data over two densities respectively. The latest tester at combined data over two densities were Gm 1002 for all characters except $L_{1} D_{1} D_{2}$.

The differences between number of days to $50 \%$ tasseling for all crosses were earliest than both single crosses 162 and 168; All 27 top crosses were significantly earlier than the best check SC 162 and SC $168 . \mathrm{L}_{1} \mathrm{~L}_{2} \mathrm{D}_{1}$ had 26 crosses significantly earlier than the best check SC 162 and SC 168. Days to $50 \%$ tasseling were ranged from 53.50 to 58.67 days in $\mathrm{L}_{1} \mathrm{~L}_{2} \mathrm{D}_{1}, 53.17$ to 56.33 days in $\mathrm{L}_{1} \mathrm{~L}_{2} \mathrm{D}_{2}, 54.17$ to 57.84 days in $\mathrm{L}_{1} \mathrm{D}_{1} \mathrm{D}_{2}$, and 52.17 to 57.17 days in $\mathrm{L}_{2} \mathrm{D}_{1} \mathrm{D}_{2}$. The earliest crosses were $\mathrm{P}_{5} \times \mathrm{Gm}$ 174 in $\mathrm{L}_{1} \mathrm{~L}_{2} \mathrm{D}_{1}, \mathrm{~L}_{1} \mathrm{~L}_{2} \mathrm{D}_{2}$ and $\mathrm{L}_{2} \mathrm{D}_{1} \mathrm{D}_{2}, \mathrm{P}_{4} \times \mathrm{Gm} 174$ and $\mathrm{P}_{4} \times \mathrm{Gm} 1021$ in $\mathrm{L}_{2} \mathrm{D}_{1} \mathrm{D}_{2}$ than S.C 162 and Sc168. Similar results were obtained by Abd El-Aty and Katta (2002); Nawar et al. (2002) and Machado et al. (2009).

Means of days to $50 \%$ silking for genotypes are presented in Table 5. The differences between number of days to $50 \%$ silking for lines and testers were highly significant in two location under two density. Number of days from sowing to $50 \%$ silking were ranged from 55.33 to 61.33 days in $\mathrm{L}_{1} \mathrm{~L}_{2} \mathrm{D}_{1}, 56$ to 60.33 days in $\mathrm{L}_{1} \mathrm{~L}_{2} \mathrm{D}_{2}$, 56.67 to 60.84 days in $\mathrm{L}_{1} \mathrm{D}_{1} \mathrm{D}_{2}$, and 53.84 to 61.50 days in $\mathrm{L}_{2} \mathrm{D}_{1} \mathrm{D}_{2}$. The earliest line in $50 \%$ silking was $\mathrm{P}_{1}($ line 10$)$ in $\mathrm{L}_{1} \mathrm{~L}_{2} \mathrm{D}_{1}, \mathrm{~L}_{1} \mathrm{~L}_{2} \mathrm{D}_{2}$ and $\mathrm{L}_{2} \mathrm{D}_{1} \mathrm{D}_{2}, \mathrm{P}_{3}$ (line 12) in $\mathrm{L}_{1} \mathrm{~L}_{2} \mathrm{D}_{2}, \mathrm{P}_{8}$ (line 32) $L_{1} D_{1} D_{2}$. Meanwhile, line $P_{4}$ (line 17) in $L_{1} L_{2} D_{2}$ and $\mathrm{L}_{2} \mathrm{D}_{1} \mathrm{D}_{2}$ and $\mathrm{P}_{5}\left(\right.$ line 20) in $\mathrm{L}_{1} \mathrm{~L}_{2} \mathrm{D}_{2}$ and $\mathrm{L}_{1} \mathrm{D}_{1} \mathrm{D}_{2}$ and $\mathrm{P}_{7}$ (line 26) in $\mathrm{L}_{1} \mathrm{~L}_{2} \mathrm{D}_{1}$, were the latest lines at combined data over two densities, respectively. For testers the earliest tester in 50\% silking was Gm174 for all characters, were the latest testers at combined data over two densities were Gm 1002 in $\mathrm{L}_{1} \mathrm{~L}_{2} \mathrm{D}_{1}, \mathrm{~L}_{2} \mathrm{D}_{1} \mathrm{D}_{2}$ and $\mathrm{Gm} 1021$ in $\mathrm{L}_{1} \mathrm{~L}_{2} \mathrm{D}_{2}$ and $\mathrm{L}_{1} \mathrm{D}_{1} \mathrm{D}_{2}$, respectively.

The differences between number of days to $50 \%$ silking for all crosses were earliest than both single crosses
162 and 168. All 27 top crosses showed that significantly earlier than both checks SC 162 and SC 168 for all characters, had 26 crosses were significantly earlier than the best check SC 162 and SC 168. Days to 50\% silking were ranged from 53.67 to 58.83 in $\mathrm{L}_{1} \mathrm{~L}_{2} \mathrm{D}_{1}, 53.67$ to 56.67 in $\mathrm{L}_{1} \mathrm{~L}_{2} \mathrm{D}_{2}, 54.50$ to 57.34 in $\mathrm{L}_{1} \mathrm{D}_{1} \mathrm{D}_{2}$, and 53 to 58.17 in $\mathrm{L}_{2} \mathrm{D}_{1} \mathrm{D}_{2}$. The earliest crosses were $\mathrm{P}_{5} \times \mathrm{Gm} 174$ in $\mathrm{L}_{1} \mathrm{~L}_{2} \mathrm{D}_{1}, \mathrm{~L}_{1} \mathrm{D}_{1} \mathrm{D}_{2}, \mathrm{P}_{4} \times \mathrm{Gm} 174$ in $\mathrm{L}_{2} \mathrm{D}_{1}, \mathrm{~L}_{2} \mathrm{D}_{2}, \mathrm{~L}_{2} \mathrm{D}_{1} \mathrm{D}_{2}$, $\mathrm{P}_{8} \times \mathrm{Gm} 1021$ in $\mathrm{L}_{1} \mathrm{~L}_{2} \mathrm{D}_{2}$ and $\mathrm{L}_{1} \mathrm{D}_{1} \mathrm{D}_{2}$ and $\mathrm{P}_{9} \times \mathrm{Gm} 1021$ in $\mathrm{L}_{1} \mathrm{D}_{1} \mathrm{D}_{2}$ than S.C 162 and $\mathrm{SC} 168$. Similar results were obtained by Abd El-Aty and Katta (2002); Nawar et al. (2002) and Machado et al. (2009).

Means of plant height for genotypes at combined data over two densities were presented in Table (6) The differences between plant height for parental inbred lines were high significant. Plant height were ranged from 157 cm to $179.67 \mathrm{~cm}$ in $\mathrm{L}_{1} \mathrm{~L}_{2} \mathrm{D}_{1}, 125.67 \mathrm{~cm}$ to $157.17 \mathrm{~cm}$ in $\mathrm{L}_{1} \mathrm{~L}_{2} \mathrm{D}_{2}, 140.84 \mathrm{~cm}$ to $186.17 \mathrm{~cm}$ in $\mathrm{L}_{1} \mathrm{D}_{1} \mathrm{D}_{2}$, and 141.84 $\mathrm{cm}$ to $162.67 \mathrm{~cm}$ in $\mathrm{L}_{2} \mathrm{D}_{1} \mathrm{D}_{2}$. The tallest line was $\mathrm{P}_{2}$ (line 11) in $L_{1} L_{2} D_{1}$ and $L_{1} D_{1} D_{2}$. Meanwhile, line $P_{5}$ (line 20) were the shortest lines in combined data over two densities respectively. For tester the tallest tester was Gm174 for all characters. Were the shortest tester in combined over two densities were $\mathrm{Gm} 1002$ in $\mathrm{L}_{1} \mathrm{D}_{1} \mathrm{D}_{2}, \mathrm{Gm} 1021$ in $\mathrm{L}_{1} \mathrm{~L}_{2} \mathrm{D}_{1}$, $\mathrm{L}_{1} \mathrm{~L}_{2} \mathrm{D}_{2}$ and $\mathrm{L}_{2} \mathrm{D}_{1} \mathrm{D}_{2}$ respectively.

The differences between plant height for crosses were highly significant compared to both single crosses 162 and 168. 27 crosses showed that significantly shorter than both checks SC 162 and SC $168 \mathrm{~L}_{1} \mathrm{~L}_{2} \mathrm{D}_{1}, \mathrm{~L}_{2} \mathrm{D}_{1} \mathrm{D}_{2}, 26$ crosses in $\mathrm{L}_{1} \mathrm{D}_{1} \mathrm{D}_{2}, 18$ crosses in $\mathrm{L}_{2} \mathrm{D}_{2}, 17$ crosses in $\mathrm{L}_{1} \mathrm{~L}_{2} \mathrm{D}_{1}$ were significantly shorter than the best check SC 162 and SC 168. Plant height ranged from $213.83 \mathrm{~cm}$ to $241.33 \mathrm{~cm}$ in $\mathrm{L}_{1} \mathrm{~L}_{2} \mathrm{D}_{1}, 208.83 \mathrm{~cm}$ to $238.33 \mathrm{~cm}$ in $\mathrm{L}_{1} \mathrm{~L}_{2} \mathrm{D}_{2}$, $206.17 \mathrm{~cm}$ to $250.17 \mathrm{~cm}$ in $\mathrm{L}_{1} \mathrm{D}_{1} \mathrm{D}_{2}$, and $219.17 \mathrm{~cm}$ to $229.17 \mathrm{~cm}$ in $\mathrm{L}_{2} \mathrm{D}_{1} \mathrm{D}_{2}$. These results are in agreement with findings by Abd El-Aty and Katta (2002); Nawar et al. (2002) and Machado et al. (2009).

Means of ear height for genotypes are presented in Table (6) The differences between ear height for lines and testers at combined data over two densities ranged from $73.33 \mathrm{~cm}$ to $92.67 \mathrm{~cm}$ in $\mathrm{L}_{1} \mathrm{~L}_{2} \mathrm{D}_{1}, 60.67 \mathrm{~cm}$ to $82.83 \mathrm{~cm}$ in $\mathrm{L}_{1} \mathrm{~L}_{2} \mathrm{D}_{2}, 60 \mathrm{~cm}$ to $96.17 \mathrm{~cm}$ in $\mathrm{L}_{1} \mathrm{D}_{1} \mathrm{D}_{2}$, and from 73.67 $\mathrm{cm}$ to $81.67 \mathrm{~cm}$ in $\mathrm{L}_{2} \mathrm{D}_{1} \mathrm{D}_{2}$. Meanwhile, lines $\mathrm{P}_{5}$ (line 20) in al characters was lowest line at all environment except in $\mathrm{L}_{2} \mathrm{D}_{1}$.

The differences between ear heights for crosses were highly significant over both single crosses 162 and 168. All 27 top crosses showed that significantly lower ear height than both checks SC 162 and SC 168 at combined 
data over two densities. Ear height ranged from $104.67 \mathrm{~cm}$ to $120.83 \mathrm{~cm}$ in $\mathrm{L}_{1} \mathrm{~L}_{2} \mathrm{D}_{1}, 96 \mathrm{~cm}$ to $115.17 \mathrm{~cm}$ in $\mathrm{L}_{1} \mathrm{~L}_{2} \mathrm{D}_{2}$, $91.34 \mathrm{~cm}$ to $121.17 \mathrm{~cm}$ in $\mathrm{L}_{1} \mathrm{D}_{1} \mathrm{D}_{2}$, and from $108.34 \mathrm{~cm}$ to $116 \mathrm{~cm}$ in $\mathrm{L}_{2} \mathrm{D}_{1} \mathrm{D}_{2}$. These results are supported by those concluded by Abd El-Aty and katta (2002) and Nawar et al. (2002)).

Ear position for genotypes are presented in Table 7. The differences between ear position for lines and testers were high significant over combined data under two densities. The highest ear placement were recorded by $\mathrm{P}_{1}$ (line 10) and $\mathrm{Gm} 1021$ in combined data over two densities. Meanwhile, parents $\mathrm{P}_{8}($ line 32$)$ and Gm174 had lowest ear placement.

The differences between ear position for crosses were highly significant. However all crosses were significantly lower ear placement than both checks SC 162 and SC 168. It may indicated that ear position is better influenced by different agronomic treatments. These results are supported by those concluded by Abd El-Aty and Katta (2002) and Nawar et al. (2002) ).

Means of grain yield per feddan for genotypes are presented in Table (7). The differences between grain yield for lines and testers were highly significant at combined data over densities. Grain yield per fed. ranged from 8.50 $\operatorname{ard} /$ fed to $18.46 \mathrm{ard} / \mathrm{fed}$ in $\mathrm{L}_{1} \mathrm{~L}_{2} \mathrm{D}_{1}, 10.16 \mathrm{ard} / \mathrm{fed}$ to 17.63 $\operatorname{ard} /$ fed in $\mathrm{L}_{1} \mathrm{~L}_{2} \mathrm{D}_{2}, 8.71 \mathrm{ard} /$ fed to $18.89 \mathrm{ard} /$ fed in $\mathrm{L}_{1} \mathrm{D}_{1} \mathrm{D}_{2}$ , and from $10.40 \mathrm{ard} /$ fed to $17.98 \mathrm{ard} /$ fed in $\mathrm{L}_{2} \mathrm{D}_{1} \mathrm{D}_{2}$.

The differences between grain yield for crosses were highly significant for most crosses at combined data over densities. Out of 27 crosses , 7 crosses were significantly higher than checks SC 162 and SC 168 in $\mathrm{L}_{1} \mathrm{~L}_{2} \mathrm{D}_{1}, 8$ crosses were significantly higher than checks SC 162 and SC 168 in $\mathrm{L}_{1} \mathrm{~L}_{2} \mathrm{D}_{2}, 5$ crosses were significantly higher than checks SC 162 and SC 168 in $\mathrm{L}_{1} \mathrm{D}_{1} \mathrm{D}_{1}$ and 11 crosses were significantly higher than checks SC 162 and SC 168 in $\mathrm{L}_{2} \mathrm{D}_{1} \mathrm{D}_{2}$. These crosses were significantly out yielded the two checks SC 162 and SC 168 at 5\%and 1\%. $\mathrm{P}_{6} \times \mathrm{Gm} 1021$ had highly significant and significant at combined over densities, $\mathrm{P}_{1} \times \mathrm{Gm} 174$ had highly significant and significant in all traits at combined over densities, $\mathrm{P}_{7} \times \mathrm{Gm} 1021$ had highly significant and significant in all traits over combined under density and $\mathrm{P}_{8} \times \mathrm{Gm} 1021$ had highly significant and significant in all traits over combined under density except $\mathrm{L}_{1} \mathrm{D}_{1} \mathrm{D}_{2}$. Hence it could be concluded that these crosses may be useful for improving grain yield of maize. Similar results were reported by Abd El-Aty and Katta (2002) and Machado et al. (2009).

Table 5. Mean Performance of maize genotypes for days to50\% tasseling and days to 50\% silking at combined data over two locations and two densities.

\begin{tabular}{|c|c|c|c|c|c|c|c|c|c|}
\hline & \multicolumn{4}{|c|}{ Days to 50\% tasseling } & \multicolumn{4}{|c|}{ Days to $50 \%$ silking } \\
\hline & & $\mathbf{L}_{1} \mathbf{L}_{2} \mathbf{D}_{1}$ & $\mathbf{L}_{1} \mathbf{L}_{2} \mathbf{D}_{2}$ & $\mathbf{L}_{1} \mathbf{D}_{1} \mathbf{D}_{2}$ & $\mathbf{L}_{2} \mathbf{D}_{1} \mathbf{D}_{2}$ & $\mathbf{L}_{1} \mathbf{L}_{2} \mathbf{D}_{1}$ & $\mathbf{L}_{1} \mathbf{L}_{2} \mathbf{D}_{2}$ & $\mathbf{L}_{1} \mathbf{D}_{1} \mathbf{D}_{2}$ & $\mathbf{L}_{2} \mathbf{D}_{1} \mathbf{D}_{2}$ \\
\hline$\overline{\mathrm{P}_{1}(\text { line } 10)}$ & & 54.83 & 55.17 & 57.00 & 53.00 & 55.33 & 56.00 & 57.50 & 53.84 \\
\hline $\mathrm{P}_{2}($ line 11$)$ & & 56.00 & 57.00 & 57.50 & 55.50 & 56.17 & 57.50 & 57.17 & 56.50 \\
\hline $\mathrm{P}_{3}($ line 12$)$ & & 57.67 & 55.33 & 57.17 & 55.84 & 57.67 & 56.00 & 56.84 & 56.84 \\
\hline $\mathrm{P}_{4}($ line 17$)$ & & 57.67 & 58.00 & 57.00 & 58.67 & 58.33 & 58.33 & 57.00 & 59.67 \\
\hline $\mathrm{P}_{5}($ line 20$)$ & & 58.33 & 57.83 & 58.50 & 57.67 & 58.83 & 58.83 & 58.34 & 59.34 \\
\hline $\mathrm{P}_{6}($ line 21$)$ & & 56.83 & 56.50 & 58.33 & 55.00 & 56.83 & 56.83 & 57.67 & 56.00 \\
\hline $\mathrm{P}_{7}($ line 26$)$ & & 59.33 & 57.00 & 58.17 & 58.17 & 59.50 & 57.67 & 57.83 & 59.34 \\
\hline $\mathrm{P}_{8}($ line 32$)$ & & 55.33 & 56.33 & 57.00 & 54.67 & 55.83 & 56.67 & 56.67 & 55.84 \\
\hline $\mathrm{P}_{9}($ line 48) & & 57.33 & 58.33 & 56.50 & 59.17 & 59.33 & 58.00 & 57.83 & 59.50 \\
\hline Gm 174 & & 58.83 & 57.67 & 59.00 & 57.50 & 59.00 & 57.67 & 58.33 & 58.34 \\
\hline Gm 1002 & & 60.83 & 59.67 & 60.17 & 60.33 & 61.33 & 59.83 & 59.67 & 61.50 \\
\hline Gm 1021 & & 59.50 & 59.33 & 60.50 & 58.34 & 59.83 & 60.33 & 60.84 & 59.34 \\
\hline $\mathrm{P}_{1} \times \mathrm{Gm} 174$ & & 54.17 & 54.50 & 55.00 & 53.67 & 54.50 & 54.83 & 54.67 & 54.67 \\
\hline $\mathrm{P}_{1} \times \mathrm{Gm} 1002$ & & 58.67 & 56.33 & 57.84 & 57.17 & 58.83 & 56.67 & 57.34 & 58.17 \\
\hline $\mathrm{P}_{1} \times \mathrm{Gm} 1021$ & & 54.50 & 53.17 & 54.17 & 53.50 & 54.83 & 54.17 & 54.67 & 54.33 \\
\hline $\mathrm{P}_{2} \times \mathrm{Gm} 174$ & & 54.67 & 54.33 & 55.34 & 53.67 & 55.17 & 55.00 & 55.33 & 54.84 \\
\hline $\mathrm{P}_{2} \times \mathrm{Gm} 1002$ & & 54.33 & 53.67 & 55.34 & 52.67 & 55.00 & 54.33 & 55.50 & 53.84 \\
\hline $\mathrm{P}_{2} \times \mathrm{Gm} 1021$ & & 53.83 & 53.50 & 55.00 & 52.34 & 54.17 & 54.00 & 55.00 & 53.17 \\
\hline $\mathrm{P}_{3} \times \mathrm{Gm} 174$ & & 54.67 & 53.50 & 55.00 & 53.17 & 55.17 & 54.00 & 54.84 & 54.34 \\
\hline $\mathrm{P}_{3} \times \mathrm{Gm} 1002$ & & 55.00 & 54.00 & 55.50 & 53.50 & 55.33 & 55.00 & 55.67 & 54.67 \\
\hline $\mathrm{P}_{3} \times \mathrm{GM} 1021$ & & 54.67 & 53.83 & 55.34 & 53.17 & 55.17 & 54.33 & 55.50 & 54.00 \\
\hline $\mathrm{P}_{4} \times \mathrm{Gm} 174$ & & 54.17 & 53.67 & 55.67 & 52.17 & 54.17 & 54.50 & 55.67 & 53.00 \\
\hline $\mathrm{P}_{4} \times \mathrm{Gm} 1002$ & & 57.17 & 54.50 & 57.17 & 54.50 & 57.83 & 55.17 & 57.17 & 55.84 \\
\hline $\mathrm{P}_{4} \times \mathrm{Gm} 1021$ & & 53.83 & 53.83 & 55.50 & 52.17 & 54.33 & 54.50 & 55.67 & 53.17 \\
\hline $\mathrm{P}_{5} \times \mathrm{Gm} 174$ & & 53.50 & 53.17 & 54.50 & 52.17 & 53.67 & 54.00 & 54.50 & 53.17 \\
\hline $\mathrm{P}_{5} \times \mathrm{Gm} 1002$ & & 55.83 & 54.67 & 57.17 & 53.33 & 56.00 & 55.50 & 56.83 & 54.67 \\
\hline $\mathrm{P}_{5} \times \mathrm{Gm} 1021$ & & 54.33 & 53.50 & 55.00 & 52.84 & 55.00 & 54.17 & 55.17 & 54.00 \\
\hline $\mathrm{P}_{6} \times \mathrm{Gm} 174$ & & 54.33 & 53.33 & 54.84 & 52.84 & 54.83 & 54.17 & 55.17 & 53.84 \\
\hline $\mathrm{P}_{6} \times \mathrm{Gm} 1002$ & & 54.67 & 54.00 & 55.50 & 53.17 & 55.17 & 55.00 & 56.00 & 54.17 \\
\hline $\mathrm{P}_{6} \times \mathrm{Gm} 1021$ & & 54.67 & 53.83 & 55.50 & 53.00 & 55.67 & 54.50 & 55.67 & 54.50 \\
\hline $\mathrm{P}_{7} \times \mathrm{Gm} 174$ & & 54.33 & 54.17 & 55.17 & 53.34 & 55.33 & 55.00 & 55.50 & 54.84 \\
\hline $\mathrm{P}_{7} \times \mathrm{Gm} 1002$ & & 54.83 & 54.17 & 55.83 & 53.17 & 55.50 & 54.83 & 56.00 & 54.34 \\
\hline $\mathrm{P}_{7} \times \mathrm{Gm} 1021$ & & 54.00 & 54.33 & 55.34 & 53.00 & 54.50 & 54.67 & 55.50 & 53.67 \\
\hline $\mathrm{P}_{8} \times \mathrm{Gm} 174$ & & 54.83 & 54.33 & 56.33 & 52.83 & 55.33 & 54.50 & 56.33 & 53.50 \\
\hline $\mathrm{P}_{8} \times \mathrm{Gm} 1002$ & & 54.33 & 54.33 & 55.84 & 52.84 & 54.67 & 54.83 & 56.00 & 53.50 \\
\hline $\mathrm{P}_{8} \times \mathrm{Gm} 1021$ & & 54.00 & 53.33 & 55.00 & 52.33 & 54.33 & 53.67 & 54.50 & 53.50 \\
\hline $\mathrm{P}_{9} \times \mathrm{Gm} 174$ & & 54.83 & 54.50 & 55.34 & 54.00 & 55.00 & 54.83 & 54.67 & 55.17 \\
\hline $\mathrm{P}_{9} \times \mathrm{Gm} 1002$ & & 53.83 & 53.50 & 54.50 & 52.84 & 54.50 & 54.33 & 55.00 & 53.84 \\
\hline $\mathrm{P}_{9} \times \mathrm{Gm} 1021$ & & 53.50 & 53.67 & 54.67 & 52.50 & 53.83 & 54.17 & 54.50 & 53.50 \\
\hline Sc 162 & & 62.83 & 62.17 & 64.00 & 61.00 & 63.33 & 61.47 & 63.63 & 61.17 \\
\hline Sc 168 & & 61.67 & 61.63 & 62.47 & 60.83 & 62.67 & 61.83 & 63.17 & 61.33 \\
\hline \multirow[t]{2}{*}{$\overline{\mathrm{LSD}}$} & 0.05 & 2.35 & 1.70 & 1.87 & 1.87 & 2.27 & 1.78 & 1.83 & 1.91 \\
\hline & 0.01 & 3.08 & 2.23 & 2.46 & 2.46 & 2.98 & 2.33 & 2.40 & 2.50 \\
\hline
\end{tabular}

Abbreviations: $L_{1}$ location Gemmeiza ; $L_{2}$ location Mallawy; $D_{1}$ density one (30000 plant / fed.) and $D_{2}$ density two (24000 plant / fed.). 
J. Plant Production, Mansoura Univ., Vol. 9 (9), September, 2018

Table 6 . Mean Performance of maize genotypes for plant height and ear height (cm)at combined data over two locations and two densities.

\begin{tabular}{|c|c|c|c|c|c|c|c|c|c|}
\hline \multirow[b]{3}{*}{$\mathrm{P}_{1}($ line 10$)$} & & \multicolumn{4}{|c|}{ Plant height (cm) } & \multicolumn{4}{|c|}{ Ear height (cm) } \\
\hline & & $\mathbf{L}_{1} \mathbf{L}_{2} \mathbf{D}_{1}$ & $\mathbf{L}_{1} \mathbf{L}_{2} \mathbf{D}_{2}$ & $\mathbf{L}_{1} \mathbf{D}_{1} \mathbf{D}_{2}$ & $\mathbf{L}_{2} \mathbf{D}_{1} \mathbf{D}_{2}$ & $\mathbf{L}_{1} \mathbf{L}_{2} \mathbf{D}_{1}$ & $\mathbf{L}_{1} \mathbf{L}_{2} \mathbf{D}_{2}$ & $\mathbf{L}_{1} \mathbf{D}_{1} \mathbf{D}_{2}$ & $\mathbf{L}_{2} \mathbf{D}_{1} \mathbf{D}_{2}$ \\
\hline & & 165.83 & 147.83 & 170.84 & 142.84 & 90.50 & 82.83 & 92.17 & 81.17 \\
\hline $\mathrm{P}_{2}($ line 11$)$ & & 179.67 & 155.17 & 186.17 & 148.67 & 92.67 & 78.00 & 94.00 & 76.67 \\
\hline $\mathrm{P}_{3}($ line 12$)$ & & 174.50 & 153.17 & 165.00 & 162.67 & 84.33 & 72.83 & 75.50 & 81.67 \\
\hline $\mathrm{P}_{4}($ line 17$)$ & & 159.00 & 144.00 & 156.17 & 146.84 & 76.83 & 76.50 & 74.83 & 78.50 \\
\hline$P_{5}($ line 20$)$ & & 157.00 & 125.67 & 140.84 & 141.84 & 73.33 & 60.67 & 60.00 & 74.00 \\
\hline $\mathrm{P}_{6}($ line 21$)$ & & 173.17 & 144.67 & 168.00 & 149.84 & 88.17 & 71.50 & 84.34 & 75.34 \\
\hline $\mathrm{P}_{7}($ line 26$)$ & & 164.17 & 131.00 & 147.17 & 148.00 & 82.83 & 69.17 & 77.84 & 74.17 \\
\hline $\mathrm{P}_{8}($ line 32$)$ & & 175.50 & 154.83 & 171.17 & 159.17 & 80.83 & 70.50 & 73.17 & 78.17 \\
\hline $\mathrm{P}_{9}($ line 48$)$ & & 175.00 & 157.17 & 176.84 & 155.33 & 90.67 & 77.00 & 90.67 & 77.00 \\
\hline Gm 174 & & 191.83 & 159.50 & 192.17 & 159.17 & 92.00 & 77.83 & 96.17 & 73.67 \\
\hline $\mathrm{Gm} 1002$ & & 180.83 & 150.83 & 177.83 & 153.83 & 86.67 & 79.33 & 87.50 & 78.50 \\
\hline Gm 1021 & & 176.50 & 147.17 & 180.67 & 143.00 & 89.17 & 76.00 & 89.84 & 75.34 \\
\hline $\mathrm{P}_{1} \times \mathrm{Gm} 174$ & & 241.33 & 228.33 & 250.17 & 219.50 & 120.83 & 109.17 & 121.17 & 108.84 \\
\hline $\mathrm{P}_{1} \times \mathrm{Gm} 1002$ & & 225.33 & 212.17 & 208.83 & 228.67 & 115.50 & 98.83 & 98.33 & 116.00 \\
\hline $\mathrm{P}_{1} \times \mathrm{Gm} 1021$ & & 216.33 & 223.83 & 213.83 & 226.33 & 108.00 & 109.83 & 101.84 & 116.00 \\
\hline $\mathrm{P}_{2} \times \mathrm{Gm} 174$ & & 228.00 & 218.67 & 222.33 & 224.34 & 115.50 & 110.00 & 112.17 & 113.34 \\
\hline $\mathrm{P}_{2} \times \mathrm{Gm} 1002$ & & 231.00 & 229.50 & 237.34 & 223.17 & 115.17 & 109.33 & 110.50 & 114.00 \\
\hline $\mathrm{P}_{2} \times \mathrm{Gm} 1021$ & & 215.83 & 217.33 & 214.00 & 219.17 & 105.67 & 107.17 & 103.00 & 109.84 \\
\hline $\mathrm{P}_{3} \times \mathrm{Gm} 174$ & & 222.67 & 238.33 & 231.84 & 229.17 & 115.33 & 114.00 & 113.00 & 116.34 \\
\hline $\mathrm{P}_{3} \times \mathrm{Gm} 1002$ & & 232.17 & 232.50 & 235.50 & 229.17 & 120.17 & 115.17 & 117.33 & 118.00 \\
\hline $\mathrm{P}_{3} \times \mathrm{GM} 102$ & & 220.83 & 217.00 & 216.83 & 221.00 & 108.17 & 105.83 & 101.17 & 112.84 \\
\hline $\mathrm{P}_{4} \times \mathrm{Gm} 174$ & & 220.83 & 220.67 & 217.17 & 224.33 & 107.17 & 109.00 & 105.17 & 111.00 \\
\hline $\mathrm{P}_{4} \times \mathrm{Gm} 1002$ & & 223.67 & 212.83 & 213.17 & 223.34 & 111.33 & 104.17 & 104.67 & 110.84 \\
\hline $\mathrm{P}_{4} \times \mathrm{Gm} 1021$ & & 213.83 & $\begin{array}{l}212.03 \\
217.00\end{array}$ & 208.00 & 222.83 & 110.17 & 105.67 & $\begin{array}{l}104.0 / \\
107.50\end{array}$ & $\begin{array}{l}110.04 \\
108.34\end{array}$ \\
\hline $\mathrm{P}_{5} \times \mathrm{Gm} 174$ & & 220.83 & 214.67 & 210.17 & 225.34 & 110.67 & 103.00 & 100.50 & 113.17 \\
\hline $\mathrm{P}_{5} \times \mathrm{Gm} 1002$ & & 229.50 & 208.83 & 216.17 & 222.17 & 117.17 & 104.00 & 106.84 & 114.33 \\
\hline $\mathrm{P}_{5} \times \mathrm{Gm} 1021$ & & 228.00 & 222.33 & 229.17 & 221.17 & 116.17 & 115.33 & 117.67 & 113.84 \\
\hline $\mathrm{P}_{6} \times \mathrm{Gm} 174$ & & 224.17 & 216.33 & 221.34 & 219.17 & 110.83 & 105.67 & 103.50 & 113.00 \\
\hline $\mathrm{P}_{6} \times \mathrm{Gm} 1002$ & & 219.50 & 208.83 & 206.17 & 222.17 & 108.17 & 96.00 & 91.34 & 112.83 \\
\hline $\mathrm{P}_{6} \times \mathrm{Gm} 1021$ & & 220.17 & 219.67 & 217.17 & 222.67 & 107.17 & 106.50 & 105.00 & 108.67 \\
\hline $\mathrm{P}_{7} \times \mathrm{Gm} 174$ & & 222.33 & 206.67 & 208.00 & 221.00 & 115.00 & 99.67 & 102.67 & 112.00 \\
\hline $\mathrm{P}_{7} \times \mathrm{Gm} 1002$ & & 224.17 & 211.83 & 214.34 & 221.67 & 114.50 & 105.67 & 108.84 & 111.34 \\
\hline $\mathrm{P}_{7} \times \mathrm{Gm} 1021$ & & 232.17 & 223.17 & 226.50 & 228.84 & 114.33 & 108.33 & 110.00 & 112.67 \\
\hline $\mathrm{P}_{8} \times \mathrm{Gm} 174$ & & 223.33 & 218.67 & 219.17 & 222.84 & 113.50 & 110.50 & 111.83 & 112.17 \\
\hline $\mathrm{P}_{8} \times \mathrm{Gm} 1002$ & & 223.00 & 211.67 & 207.50 & 227.17 & 104.67 & 100.67 & 96.33 & 109.00 \\
\hline $\mathrm{P}_{8} \times \mathrm{Gm} 1021$ & & 223.33 & 216.17 & 214.67 & 224.83 & 114.50 & 111.83 & 110.84 & 115.50 \\
\hline $\mathrm{P}_{9} \times \mathrm{Gm} 174$ & & 218.33 & 213.00 & 209.00 & 222.34 & 113.83 & 110.67 & 108.50 & 116.00 \\
\hline $\mathrm{P}_{9} \times \mathrm{Gm} 1002$ & & 218.17 & 232.33 & 226.33 & 224.17 & 109.00 & 108.83 & 104.00 & 113.84 \\
\hline $\mathrm{P}_{0} \times \mathrm{Gm} 1021$ & & 221.17 & 232.33 & 227.67 & 225.84 & 106.83 & 112.67 & 107.34 & 112.17 \\
\hline Sc 162 & & 260.83 & 256.97 & 265.80 & 252.00 & 175.97 & 158.63 & 170.10 & 164.50 \\
\hline Sc 168 & & 260.30 & 251.63 & 265.10 & 246.83 & 171.67 & 150.98 & 168.65 & 154.00 \\
\hline LSD & 0.05 & 12.73 & 22.47 & 13.97 & 12.67 & 9.76 & 10.88 & 9.08 & 7.63 \\
\hline & 0.01 & 16.69 & 29.46 & 18.31 & 16.62 & 12.80 & 14.27 & 11.90 & 10.00 \\
\hline
\end{tabular}

Abbreviations: $L_{1}$ location Gemmeiza ; $L_{2}$ location Mallawy; $D_{1}$ density one (30000 plant / fed.) and $D_{2}$ density two (24000 plant / fed.)

Table 7. Mean Performance of maize genotypes for ear position (\%) and grain yield at combined over two locations and two

\begin{tabular}{|c|c|c|c|c|c|c|c|c|}
\hline & \multicolumn{4}{|c|}{ Ear position (\%) } & \multicolumn{4}{|c|}{ Grain yield (ard./fed. } \\
\hline & $\mathbf{L}_{1} \mathbf{L}_{2} \mathbf{D}_{1}$ & $\mathbf{L}_{1} \mathbf{L}_{2} \mathbf{D}_{2}$ & $\mathbf{L}_{1} \mathbf{D}_{1} \mathbf{D}_{2}$ & $\mathbf{L}_{2} \mathbf{D}_{1} \mathbf{D}_{2}$ & $\mathbf{L}_{1} \mathbf{L}_{2} \mathbf{D}_{1}$ & $\mathbf{L}_{1} \mathbf{L}_{2} \mathbf{D}_{2}$ & $\mathbf{L}_{1} \mathbf{D}_{1} \mathbf{D}_{2}$ & $\mathbf{L}_{2} \mathbf{D}_{1} \mathbf{D}_{2}$ \\
\hline$\overline{P_{1}(\text { line } 10)}$ & 54.70 & 56.72 & 54.01 & 57.41 & 13.83 & 14.71 & 15.76 & 12.78 \\
\hline $\mathrm{P}_{2}($ line 11$)$ & 51.63 & 50.46 & 50.55 & 51.55 & 13.35 & 15.63 & 16.20 & 12.78 \\
\hline $\mathrm{P}_{3}($ line 12$)$ & 48.24 & 48.20 & 45.76 & 50.69 & 14.28 & 15.19 & 16.17 & 13.31 \\
\hline $\mathrm{P}_{4}($ line 17$)$ & 48.28 & 54.43 & 48.04 & 54.68 & 15.82 & 16.68 & 17.46 & 15.05 \\
\hline $\mathrm{P}_{5}($ line 20$)$ & 46.35 & 49.13 & 42.58 & 52.90 & 9.48 & 10.16 & 8.71 & 10.93 \\
\hline $\mathrm{P}_{6}($ line 21$)$ & 51.13 & 50.32 & 50.32 & 51.13 & 14.08 & 15.64 & 13.80 & 15.93 \\
\hline$P_{7}($ line 26$)$ & 50.93 & 52.98 & 52.91 & 51.01 & 12.51 & 14.27 & 10.39 & 16.40 \\
\hline $\mathrm{P}_{8}($ line 32$)$ & 45.96 & 46.29 & 42.77 & 49.48 & 16.73 & 17.27 & 16.03 & 17.98 \\
\hline$P_{9}($ line 48) & 51.93 & 49.63 & 51.40 & 50.16 & 15.43 & 17.63 & 17.68 & 15.39 \\
\hline $\mathrm{Gm} 174$ & 47.99 & 50.10 & 50.06 & 48.02 & 14.20 & 10.81 & 13.74 & 11.28 \\
\hline $\mathrm{Gm} 1002$ & 48.01 & 53.08 & 49.22 & 51.88 & 8.50 & 15.29 & 12.23 & 11.57 \\
\hline $\mathrm{Gm} 1021$ & 50.49 & 53.02 & 49.79 & 53.73 & 18.46 & 16.06 & 18.89 & 15.64 \\
\hline $\mathrm{P}_{1} \times \mathrm{Gm} 174$ & 50.09 & 47.78 & 48.43 & 49.45 & 42.51 & 39.96 & 43.47 & 39.00 \\
\hline $\mathrm{P}_{1} \times \mathrm{Gm} 1002$ & 51.21 & 46.46 & 46.99 & 50.69 & 33.33 & 31.29 & 34.04 & 30.59 \\
\hline $\mathrm{P}_{1} \times \mathrm{Gm1021}$ & 49.74 & 49.12 & 47.62 & 51.25 & 33.19 & 39.75 & 39.66 & 33.29 \\
\hline $\mathrm{P}_{2} \times \mathrm{Gm} 174$ & 50.59 & 50.31 & 50.49 & 50.42 & 40.43 & 37.27 & 41.24 & 36.47 \\
\hline $\mathrm{P}_{2} \times \mathrm{Gm} 1002$ & 49.90 & 47.65 & 46.53 & 51.02 & 38.45 & 37.04 & 40.14 & 35.36 \\
\hline $\mathrm{P}_{2} \times \mathrm{Gm1021}$ & 48.93 & 49.32 & 48.12 & 50.13 & 34.11 & 39.83 & 37.34 & 36.61 \\
\hline $\mathrm{P}_{3} \times \mathrm{Gm} 174$ & 51.79 & 47.93 & 48.98 & 50.73 & 34.68 & 35.30 & 34.43 & 35.55 \\
\hline $\mathrm{P}_{3} \times \mathrm{Gm} 1002$ & 51.79 & 49.59 & 49.84 & 51.54 & 33.54 & 41.12 & 38.71 & 35.95 \\
\hline $\mathrm{P}_{3} \times \mathrm{GM} 1021$ & 48.88 & 48.84 & 46.68 & 51.04 & 35.70 & 38.93 & 42.31 & 32.33 \\
\hline $\mathrm{P}_{4} \times \mathrm{Gm} 174$ & 48.52 & 49.39 & 48.43 & 49.49 & 37.81 & 40.57 & 40.29 & 38.09 \\
\hline $\mathrm{P}_{4} \times \mathrm{Gm} 1002$ & 49.75 & 49.05 & 49.14 & 49.67 & 32.09 & 34.01 & 32.63 & 33.48 \\
\hline $\mathrm{P}_{4} \times \mathrm{Gm1021}$ & 51.61 & 48.78 & 51.76 & 48.63 & 35.19 & 34.88 & 34.46 & 35.62 \\
\hline $\mathrm{P}_{5} \times \mathrm{Gm} 174$ & 50.04 & 48.04 & 47.89 & 50.20 & 31.24 & 41.27 & 37.46 & 35.05 \\
\hline $\mathrm{P}_{5} \times \mathrm{Gm} 1002$ & 51.01 & 49.81 & 49.46 & 51.37 & 28.78 & 36.65 & 32.68 & 32.76 \\
\hline $\mathrm{P}_{5} \times \mathrm{Gm1021}$ & 50.94 & 51.84 & 51.33 & 51.47 & 37.49 & 37.35 & 39.80 & 35.04 \\
\hline $\mathrm{P}_{6} \times \mathrm{Gm} 174$ & 49.35 & 48.87 & 46.75 & 51.46 & 39.25 & 39.84 & 41.75 & 37.35 \\
\hline $\mathrm{P}_{6} \times \mathrm{Gm} 1002$ & 49.17 & 45.84 & 44.25 & 50.77 & 32.96 & 34.26 & 34.46 & 32.76 \\
\hline $\mathrm{P}_{6} \times \mathrm{Gm} 1021$ & 48.69 & 48.54 & 48.41 & 48.83 & 41.75 & 43.59 & 44.89 & 40.46 \\
\hline $\mathrm{P}_{7} \times \mathrm{Gm} 174$ & 51.77 & 48.24 & 49.36 & 50.66 & 33.74 & 39.30 & 36.93 & 36.12 \\
\hline $\mathrm{P}_{7} \times \mathrm{Gm} 1002$ & 51.08 & 49.88 & 50.78 & 50.19 & 32.09 & 39.43 & 36.98 & 34.56 \\
\hline $\mathrm{P}_{7} \times \mathrm{Gm} 1021$ & 49.20 & 48.53 & 48.57 & 49.17 & 39.39 & 40.72 & 43.82 & 36.30 \\
\hline $\mathrm{P}_{8} \times \mathrm{Gm} 174$ & 50.78 & 50.55 & 51.05 & 50.28 & 37.50 & 37.11 & 38.11 & 36.51 \\
\hline $\mathrm{P}_{8} \times \mathrm{Gm} 1002$ & 46.91 & 47.55 & 46.44 & 48.03 & 36.64 & 41.15 & 39.59 & 38.19 \\
\hline $\mathrm{P}_{8} \times \mathrm{Gm} 1021$ & 51.23 & 51.73 & 51.61 & 51.36 & 38.43 & 40.56 & 41.33 & 37.66 \\
\hline $\mathrm{P}_{9} \times \mathrm{Gm} 174$ & 52.10 & 51.95 & 51.88 & 52.18 & 34.25 & 37.85 & 34.01 & 38.09 \\
\hline $\mathrm{P}_{9} \times \mathrm{Gm} 1002$ & 49.80 & 46.94 & 46.02 & 50.73 & 36.24 & 33.94 & 34.19 & 36.01 \\
\hline $\mathrm{P}_{9} \times \mathrm{Gm1021}$ & 48.24 & 48.52 & 47.13 & 49.64 & 36.24 & 39.64 & 37.05 & 38.83 \\
\hline Sc 162 & 67.52 & 61.72 & 64.00 & 65.23 & 34.63 & 36.24 & 38.03 & 32.85 \\
\hline Sc 168 & 65.98 & 60.05 & 63.70 & 62.33 & 34.35 & 37.02 & 37.64 & 33.67 \\
\hline LSD & 4.22 & 5.42 & 3.58 & 7.63 & 3.77 & 3.48 & 3.92 & 3.44 \\
\hline 0.01 & 5.54 & 7.11 & 4.70 & 10.00 & 4.94 & 4.56 & 5.14 & 4.51 \\
\hline
\end{tabular}

Abbreviations: $L_{1}$ location Gemmeiza ; $L_{2}$ location Mallawy; $D_{1}$ density one (30000 plant / fed.) and $D_{2}$ density two (24000 plant / fed.). 


\section{General combining ability effects}

Results of GCA effects for days to $50 \%$ tasseling in table 8 show that $\mathrm{Gm} 1021$ recorded significant and negative GCA effects in $\mathrm{L}_{1} \mathrm{~L}_{2} \mathrm{D}_{1}, \mathrm{~L}_{1} \mathrm{~L}_{2} \mathrm{D}_{2}, \mathrm{~L}_{1} \mathrm{D}_{1} \mathrm{D}_{2}$ and $L_{2} D_{1} D_{2}$. Inbred line $P_{1}$ had highly significant and positively GCA effects in $\mathrm{L}_{1} \mathrm{~L}_{2} \mathrm{D}_{1}, \mathrm{~L}_{1} \mathrm{~L}_{2} \mathrm{D}_{2}$ and $\mathrm{L}_{2} \mathrm{D}_{1} \mathrm{D}_{2}$, line $\mathrm{P}_{4}$ had significant and positive GCA effects in $\mathrm{L}_{1} \mathrm{D}_{1} \mathrm{D}_{2}$ and $\mathrm{Gm} 1002$ had highly significantly positive GCA effects in $\mathrm{L}_{1} \mathrm{~L}_{2} \mathrm{D}_{1}, \mathrm{~L}_{1} \mathrm{~L}_{2} \mathrm{D}_{2}, \mathrm{~L}_{1} \mathrm{D}_{1} \mathrm{D}_{2}$ and $\mathrm{L}_{2} \mathrm{D}_{1} \mathrm{D}_{2}$. These results indicating that $\mathrm{Gm} 1021$ could be considered as a good general combiner for earliness and parental inbred line $\mathrm{P}_{1}$ (line10), $\mathrm{P}_{4}$ (line17) and $\mathrm{Gm} 1002$ could be considered as a good general combiners for lateness. Such results agree with those of Singh( 2005), Parmar (2007), and Sultan et al. (2010).

Results of GCA effects for Days to $50 \%$ silking in Table 8 showed that parental inbred line Gm 1021 had negatively highly significant and significant GCA effects in their combined data $\mathrm{L}_{1} \mathrm{~L}_{2} \mathrm{D}_{1}, \mathrm{~L}_{1} \mathrm{~L}_{2} \mathrm{D}_{2}, \mathrm{~L}_{1} \mathrm{D}_{1} \mathrm{D}_{2}$ and $\mathrm{L}_{2} \mathrm{D}_{1} \mathrm{D}_{2}, \mathrm{P}_{8}$ (line32) had significant and negative GCA effects in $L_{2} D_{1} D_{2}$ and inbred line $P_{9}$ (line48) had significant and negative GCA effects in $\mathrm{L}_{1} \mathrm{D}_{1} \mathrm{D}_{2}$. The inbred line $\mathrm{P}_{1}$ (line10) had significant and positive GCA effects in $\mathrm{L}_{1} \mathrm{~L}_{2} \mathrm{D}_{1}, \mathrm{~L}_{1} \mathrm{~L}_{2} \mathrm{D}_{2}, \mathrm{~L}_{2} \mathrm{D}_{1} \mathrm{D}_{2} ; \mathrm{P}_{4}$ (line17) had significant and positive GCA effects in $\mathrm{L}_{1} \mathrm{D}_{1} \mathrm{D}_{2}$ and $\mathrm{Gm}$ 1002 had positively highly significant and significant GCA effects in combined data $\mathrm{L}_{1} \mathrm{~L}_{2} \mathrm{D}_{1}, \mathrm{~L}_{1} \mathrm{~L}_{2} \mathrm{D}_{2}, \mathrm{~L}_{1} \mathrm{D}_{1} \mathrm{D}_{2}$ and $\mathrm{L}_{2} \mathrm{D}_{1} \mathrm{D}_{2}$. These results indicating that parental inbred line $\mathrm{Gm} 1021, \mathrm{P}_{8}$ (line32) and $\mathrm{P}_{9}$ (line 48) could be considered as a good general combiners for earliness. The inbred line $\mathrm{P}_{1}$ (line10)and Gm1002 could be considered as a good general combiners for lateness. Similar conclusions was obtained by other worker including Surya and Ganguli (2004), Singh (2005) and Sultan et al. (2010).

In Table 9 results of GCA effects for Plant height (cm) showed that parental inbred line $\mathrm{P}_{4}$ (line17) had significant and highly significant negatively GCA effects in $L_{1} L_{2} D_{1}$ and $L_{1} D_{1} D_{2}$. The parental inbred line $P_{8}$ (line 32) showed that highly significant and significant negatively GCA effects in $L_{1} D_{1} D_{2}$ and $P_{9}$ (line48) had significant and negative GCA effects in $\mathrm{L}_{1} \mathrm{~L}_{2} \mathrm{D}_{1}$. suggesting that these inbred lines are the best general combiners for plant shortness. Similar trend were obtained by Surya and Ganguli (2004),Singh (2005) and EL-Shenawy et al. (2009).
Results of GCA effects for ear height $(\mathrm{cm})$ in Table 9 showed that parental inbred line $\mathrm{P}_{4}$ had highly significant and negatively significant GCA effects in $\mathrm{L}_{2} \mathrm{D}_{1} \mathrm{D}_{2}$; inbred line $\mathrm{P}_{6}$ had highly significant and negatively significant GCA effects in $L_{1} L_{2} D_{1}, L_{1} L_{2} D_{2}$ and $L_{1} D_{1} D_{2} ; G m 1002$ had highly significant and negative GCA effects in $\mathrm{L}_{1} \mathrm{~L}_{2} \mathrm{D}_{2}$ and $\mathrm{L}_{1} \mathrm{D}_{1} \mathrm{D}_{2}$ and $\mathrm{Gm} 1021$ had significant and negative GCA effects in $L_{1} L_{2} D_{1}$. On the other side's inbred line $P_{3}$ (line 12) had significant and positive significant GCA effects in $L_{1} L_{2} D_{2}, L_{1} D_{1} D_{2}$ and $L_{2} D_{1} D_{2}$.It is suggested that parental inbred line $\mathrm{P}_{4}$ (line17) and $\mathrm{P}_{6}$ (line 21) are good general combiner for low ear height. While, parental inbred lines $\mathrm{P}_{3}$ (line 12) is the best general combiners for high ear height. Similar trend were reported by Surya and Ganguli (2004),Singh (2005) , Singh and Roy (2007) , Parmar (2007), and EL-Shenawy et al. (2009).

In Table 10 results of GCA effects for ear position ( \% ) showed that parental inbred line $\mathrm{P}_{6}$ had highly significant and negative GCA effects in $\mathrm{L}_{1} \mathrm{D}_{1} \mathrm{D}_{2}$; Parental inbred line $\mathrm{Gm} 1002$ had highly significant and negative GCA effects in $L_{1} D_{1} D_{2}$. These results suggested that $P_{6}$ (line21) and Gm 1002 inbred line could be considered as the best general combiner for lower ear placement. Similar conclusions was obtained by other workers including Singh (2005) Rakesh et al.(2006), and EL-Shenawy et al. (2009).

Results of GCA effects for grain yield Table 10 revealed that the best general combiners for increasing grain yield was $\mathrm{P}_{6}$ (line21), where it had significant and highly significant positive GCA effects in $\mathrm{L}_{1} \mathrm{~L}_{2} \mathrm{D}_{2}$ and $\mathrm{L}_{2} \mathrm{D}_{1} \mathrm{D}_{2}, \mathrm{P}_{8}$ (line 32)had significant and highly significant positive GCA effects in $\mathrm{L}_{1} \mathrm{~L}_{2} \mathrm{D}_{1}, \mathrm{~L}_{1} \mathrm{~L}_{2} \mathrm{D}_{2}, \mathrm{~L}_{1} \mathrm{D}_{1} \mathrm{D}_{2}$ and $\mathrm{L}_{2} \mathrm{D}_{1} \mathrm{D}_{2} ; \mathrm{P}_{2}$ (line 11 ) had significant and highly significant positive GCA effects in $\mathrm{L}_{1} \mathrm{~L}_{2} \mathrm{D}_{1}, \mathrm{~L}_{1} \mathrm{~L}_{2} \mathrm{D}_{2}$ and $\mathrm{L}_{1} \mathrm{D}_{1} \mathrm{D}_{2}, \mathrm{P}_{7}$ (line 26) had significant and highly significant positive GCA effects in $\mathrm{L}_{1} \mathrm{~L}_{2} \mathrm{D}_{2} . \mathrm{P}_{9}$ (line 48 ) had significant and highly significant positive GCA effects in $\mathrm{L}_{2} \mathrm{D}_{1} \mathrm{D}_{2}, \mathrm{Gm}$ 174 had significant and highly significant positive GCA effects in $\mathrm{L}_{1} \mathrm{~L}_{2} \mathrm{D}_{1}, \mathrm{~L}_{1} \mathrm{~L}_{2} \mathrm{D}_{2}$ and $\mathrm{L}_{2} \mathrm{D}_{1} \mathrm{D}_{2}$. Gm1021 had significant and highly significant positive GCA effects in $\mathrm{L}_{1} \mathrm{~L}_{2} \mathrm{D}_{1}, \mathrm{~L}_{1} \mathrm{~L}_{2} \mathrm{D}_{2}$ and $\mathrm{L}_{1} \mathrm{D}_{1} \mathrm{D}_{2}$. These results are in conformity by the finding of Welcker et al.(2005), Rakesh et al.(2006), Osman and Ibrahim (2007), Singh and Roy (2007) , Parmar (2007) , EL-Shenawy et al.(2009) and Sultan et al. (2010).

Table 8 . GCA effects of nine parents and three testers of maize for days to $50 \%$ tasseling and days to $50 \%$ silking at combined data over two locations and over two densities during growing season 2016.

\begin{tabular}{|c|c|c|c|c|c|c|c|c|c|}
\hline & \multicolumn{4}{|c|}{ Days to $50 \%$ tasseling } & \multicolumn{4}{|c|}{ Days to 50\% silking } \\
\hline & & $\mathbf{L}_{1} \mathbf{L}_{2} \mathbf{D}_{1}$ & $\mathbf{L}_{1} \mathbf{L}_{2} \mathbf{D}_{2}$ & $\mathbf{L}_{1} \mathbf{D}_{1} \mathbf{D}_{2}$ & $\mathbf{L}_{2} \mathbf{D}_{1} \mathbf{D}_{2}$ & $\mathbf{L}_{1} \mathbf{L}_{2} \mathbf{D}_{1}$ & $\mathbf{L}_{1} \mathbf{L}_{2} \mathbf{D}_{2}$ & $\mathbf{L}_{1} \mathbf{D}_{1} \mathbf{D}_{2}$ & $\mathbf{L}_{2} \mathbf{D}_{1} \mathbf{D}_{2}$ \\
\hline$\overline{\mathrm{P}_{1}(\text { line }}$ & & $1.13^{* *}$ & $0.68 *$ & 0.21 & $1.60 * *$ & $0.95 *$ & $0.60 *$ & 0.06 & $1.49^{* *}$ \\
\hline $\mathrm{P}_{2}$ (line & & -0.37 & -0.15 & -0.23 & -0.29 & -0.33 & -0.17 & -0.22 & -0.28 \\
\hline $\mathrm{P}_{3}$ (line & & 0.13 & -0.21 & -0.18 & 0.10 & 0.12 & -0.17 & -0.16 & 0.10 \\
\hline $\mathrm{P}_{4}($ line & & 0.41 & 0.01 & 0.65 & -0.23 & 0.34 & 0.10 & $0.67 *$ & -0.23 \\
\hline $\mathrm{P}_{5}$ (line & & -0.09 & -0.21 & 0.10 & -0.40 & -0.22 & -0.06 & 0.01 & -0.28 \\
\hline $\mathrm{P}_{6}$ (line & & -0.09 & -0.27 & -0.18 & -0.18 & 0.12 & -0.06 & 0.12 & -0.06 \\
\hline $\mathrm{P}_{7}($ line & & -0.26 & 0.23 & -0.01 & -0.01 & 0.01 & 0.22 & 0.17 & 0.05 \\
\hline $\mathrm{P}_{8}$ (line & & -0.26 & 0.01 & 0.27 & -0.51 & -0.33 & -0.28 & 0.12 & $-0.73 *$ \\
\hline $\mathrm{P}_{9}$ (line & & -0.59 & -0.10 & -0.62 & -0.07 & -0.66 & -0.17 & $-0.77 *$ & -0.06 \\
\hline \multirow{2}{*}{ L.S.D. } & 0.05 & 0.76 & 0.56 & 0.60 & 0.62 & 0.76 & 0.56 & 0.60 & 0.62 \\
\hline & 0.01 & 1.00 & 0.74 & 0.79 & 0.82 & 1.00 & 0.74 & 0.79 & 0.82 \\
\hline \multirow{3}{*}{\multicolumn{2}{|c|}{$\begin{array}{l}\mathrm{Gm} 174 \\
\mathrm{Gm} 1002 \\
\mathrm{Gm} 1021\end{array}$}} & -0.26 & -0.04 & -0.22 & -0.09 & -0.26 & -0.04 & -0.22 & -0.09 \\
\hline & & $0.76 * *$ & $0.36^{*}$ & $0.62 * *$ & $0.51 * *$ & $0.76 * *$ & $0.36^{*}$ & $0.62 * *$ & $0.51 * *$ \\
\hline & & $-0.50 *$ & $-0.32 *$ & $-0.40^{*}$ & $-0.42 *$ & $-0.50 *$ & $-0.32 *$ & $-0.40 *$ & $-0.42 *$ \\
\hline \multirow{2}{*}{ L.S.D. } & 0.05 & 0.45 & 0.31 & 0.35 & 0.36 & 0.45 & 0.31 & 0.35 & 0.36 \\
\hline & 0.01 & 0.59 & 0.41 & 0.46 & 0.48 & 0.59 & 0.41 & 0.46 & 0.48 \\
\hline
\end{tabular}

*, ** significant at 0.05 and 0.01 level of probability, respectively

Abbreviations: $L_{1}$ location Gemmeiza ; $L_{2}$ location Mallawy; $D_{1}$ density one (30000 plant / fed.) and $D_{2}$ density two (24000 plant / fed.). 
Table 9. GCA effects of nine lines and three testers of maize for plant height and ear height (cm) at combined data over two locations and over two densities during growing season 2016.

\begin{tabular}{|c|c|c|c|c|c|c|c|c|c|}
\hline & \multicolumn{4}{|c|}{ Plant height(cm) } & \multicolumn{4}{|c|}{ Ear height (cm) } \\
\hline & & $\mathbf{L}_{1} \mathbf{L}_{2} \mathbf{D}_{1}$ & $\mathbf{L}_{1} \mathbf{L}_{2} \mathbf{D}_{2}$ & $\mathbf{L}_{1} \mathbf{D}_{1} \mathbf{D}_{2}$ & $\mathbf{L}_{2} \mathbf{D}_{1} \mathbf{D}_{2}$ & $\mathbf{L}_{1} \mathbf{L}_{2} \mathbf{D}_{1}$ & $\mathbf{L}_{1} \mathbf{L}_{2} \mathbf{D}_{2}$ & $\mathbf{L}_{1} \mathbf{D}_{1} \mathbf{D}_{2}$ & $\mathbf{L}_{2} \mathbf{D}_{1} \mathbf{D}_{2}$ \\
\hline $\mathrm{P}_{1}$ (line & & 3.96 & 2.01 & 4.93 & 1.04 & 2.58 & -1.37 & 0.41 & 0.80 \\
\hline $\mathrm{P}_{2}$ (line & & 1.24 & 2.40 & 5.21 & -1.57 & -0.09 & 1.52 & 1.85 & -0.42 \\
\hline $\mathrm{P}_{3}$ (line & & 1.52 & $9.85 * *$ & $8.71 * *$ & 2.65 & 2.36 & $4.35 *$ & $3.80 *$ & $2.91 *$ \\
\hline $\mathrm{P}_{4}($ line & & $-4.26 *$ & -2.60 & $-6.57 * *$ & -0.29 & -2.64 & -1.04 & -0.93 & $-2.75^{*}$ \\
\hline $\mathrm{P}_{5}$ (line & & 2.41 & -4.15 & -0.85 & -0.90 & 2.47 & 0.13 & 1.63 & 0.97 \\
\hline $\mathrm{P}_{6}$ (line & & -2.43 & -4.49 & -4.46 & -2.46 & $-3.48 *$ & $-4.59 *$ & $-6.76 * *$ & -1.31 \\
\hline $\mathrm{P}_{7}$ (line & & 2.52 & -5.54 & -3.07 & 0.04 & 2.41 & -2.76 & 0.46 & -0.81 \\
\hline $\mathrm{P}_{8}$ (line & & -0.48 & -3.93 & $-5.57 *$ & 1.15 & -1.31 & 0.35 & -0.37 & -0.59 \\
\hline $\mathrm{P}_{9}$ (line & & -4.48 & 6.46 & 1.65 & 0.32 & -2.31 & 3.41 & -0.09 & 1.19 \\
\hline \multirow{2}{*}{ L.S.D. } & 0.05 & 4.23 & 7.48 & 4.64 & 6.35 & 3.25 & 3.62 & 3.01 & 2.52 \\
\hline & 0.01 & 5.564 & 9.84 & 6.10 & 8.34 & 4.276 & 4.76 & 3.96 & 3.23 \\
\hline Gm 17 & & 0.94 & 0.05 & 1.67 & 0.68 & 1.43 & 0.65 & 2.02 & 0.06 \\
\hline $\mathrm{Gm} 10$ & & 1.46 & -1.60 & -0.97 & 0.84 & 0.65 & $-2.57 * *$ & $-2.46 * *$ & 0.54 \\
\hline $\mathrm{Gm} 10$ & & -2.41 & 1.55 & -0.70 & -0.16 & $-2.09 *$ & 1.93 & 0.44 & -0.60 \\
\hline \multirow{2}{*}{ L.S.D. } & 0.05 & 3.194 & 5.66 & 3.52 & 4.81 & 1.86 & 2.07 & 1.74 & 1.45 \\
\hline & 0.01 & 5.564 & 9.84 & 6.10 & 8.34 & 2.44 & 2.73 & 2.29 & 1.90 \\
\hline
\end{tabular}

*, ** significant at 0.05 and 0.01 level of probability , respectively

Abbreviations: $L_{1}$ location Gemmeiza ; $L_{2}$ location Mallawy; $D_{1}$ density one (30000 plant / fed.) and $D_{2}$ density two (24000 plant / fed.).

Table 10. GCA effects of nine parents and three testers of maize for ear position (\%) and grain yield (ard./fed.) at combined data over two locations and over two densities during growing season 2016.

\begin{tabular}{|c|c|c|c|c|c|c|c|c|c|}
\hline & \multicolumn{4}{|c|}{ Ear position(\%) } & \multicolumn{4}{|c|}{ Grain yield (ard./fed.) } \\
\hline & & $\mathbf{L}_{1} \mathbf{L}_{2} \mathbf{D}_{1}$ & $\mathbf{L}_{1} \mathbf{L}_{2} \mathbf{D}_{2}$ & $\mathbf{L}_{1} \mathbf{D}_{1} \mathbf{D}_{2}$ & $\mathbf{L}_{2} \mathbf{D}_{1} \mathbf{D}_{2}$ & $\mathbf{L}_{1} \mathbf{L}_{2} \mathbf{D}_{1}$ & $\mathbf{L}_{1} \mathbf{L}_{2} \mathbf{D}_{2}$ & $\mathbf{L}_{1} \mathbf{D}_{1} \mathbf{D}_{2}$ & $\mathbf{L}_{2} \mathbf{D}_{1} \mathbf{D}_{2}$ \\
\hline$\overline{\mathrm{P}_{1}(\text { line }}$ & & 0.23 & -1.14 & -0.98 & 0.07 & 0.53 & $-1.25 * *$ & 0.84 & $-1.56^{*}$ \\
\hline $\mathrm{P}_{2}$ (line & & -0.31 & 0.17 & -0.28 & 0.14 & $1.85 * *$ & -0.20 & $1.36^{*}$ & 0.29 \\
\hline $\mathrm{P}_{3}$ (line & & 0.70 & -0.14 & -0.16 & 0.72 & -1.18 & 0.21 & 0.27 & $-1.24 *$ \\
\hline $\mathrm{P}_{4}($ line & & -0.15 & 0.15 & 1.11 & -1.12 & -0.78 & $-1.76 * *$ & -2.42 & -0.12 \\
\hline $\mathrm{P}_{5}($ line & & 0.55 & 0.97 & 0.89 & 0.62 & -3.31 & 0.18 & $-1.56^{*}$ & $-1.57 * *$ \\
\hline $\mathrm{P}_{6}($ line & & -1.04 & -1.18 & $-2.19 * *$ & -0.03 & $2.17 * *$ & 0.99 & $2.16 * *$ & 1.00 \\
\hline $\mathrm{P}_{7}($ line & & 0.57 & -0.04 & 0.91 & -0.38 & -0.74 & $1.57 * *$ & 1.03 & -0.20 \\
\hline $\mathrm{P}_{8}$ (line & & -0.48 & 1.02 & 1.03 & -0.49 & $1.70 * *$ & $1.36^{*}$ & $1.46^{*}$ & $1.60 * *$ \\
\hline $\mathrm{P}_{9}($ line & & -0.07 & 0.21 & -0.32 & 0.46 & -0.24 & -1.10 & $-3.13 * *$ & $1.79 * *$ \\
\hline \multirow{2}{*}{ L.S.D. } & 0.05 & 1.39 & 1.80 & 1.17 & 1.86 & 1.25 & 1.15 & 1.29 & 1.13 \\
\hline & 0.01 & 1.82 & 2.36 & 1.54 & 2.44 & 1.64 & 1.51 & 1.70 & 1.49 \\
\hline \multicolumn{2}{|c|}{$\overline{\mathrm{Gm}} 174$} & 0.44 & 0.30 & 0.59 & 0.16 & $1.00 * *$ & 0.47 & 0.42 & $1.06^{* *}$ \\
\hline \multicolumn{2}{|c|}{ Gm 1002} & -0.05 & -0.84 & $-0.95 * *$ & 0.06 & $-2.02 * *$ & $-1.70 * *$ & $-2.28 * *$ & $-1.45 * *$ \\
\hline \multicolumn{2}{|c|}{ Gm 1021} & -0.40 & 0.54 & 0.36 & -0.22 & $1.02 * *$ & $1.23 * *$ & $1.86 * *$ & 0.39 \\
\hline \multirow{2}{*}{ L.S.D. } & 0.05 & 0.80 & 1.03 & 0.68 & 1.08 & 0.70 & 0.66 & 0.74 & 0.64 \\
\hline & 0.01 & 1.05 & 1.36 & 0.90 & 1.41 & 0.92 & 0.87 & 0.97 & 0.85 \\
\hline
\end{tabular}

*, ** significant at 0.05 and 0.01 level of probability , respectively

Abbreviations: $L_{1}$ location Gemmeiza ; $L_{2}$ location Mallawy; $D_{1}$ density one (30000 plant / fed.) and $D_{2}$ density two (24000 plant / fed.).

Specific combining ability effects

Results in Table 11 for tasseling dates showed that crosses $\mathrm{P}_{1} \times \mathrm{Gm} 174$ had significant and negative SCA effects in $\mathrm{L}_{1} \mathrm{~L}_{2} \mathrm{D}_{1}, \mathrm{P}_{1} \times \mathrm{Gm} 1021$ had significant and negative SCA effects in $L_{1} L_{2} D_{2}$ and $L_{1} D_{1} D_{2}$ while $P_{1} \times G m$ 1002 in $\mathrm{L}_{1} \mathrm{~L}_{2} \mathrm{D}_{1}, \mathrm{~L}_{1} \mathrm{~L}_{2} \mathrm{D}_{2}, \mathrm{~L}_{1} \mathrm{D}_{1} \mathrm{D}_{2}$ and $\mathrm{L}_{2} \mathrm{D}_{1} \mathrm{D}_{2}$ and $\mathrm{P}_{4} \times \mathrm{Gm}$ 1002 in $\mathrm{L}_{1} \mathrm{~L}_{2} \mathrm{D}_{1}$ had significant and positive SCA effects. Indicating that crosses $\mathrm{P}_{1} \times \mathrm{Gm} 174$ and $\mathrm{P}_{1} \times \mathrm{Gm} 1021$ are the best combinations for earliness.

Results in Table 11 for silking dates cleared that cross $P_{1} \times G m 1002$ in $L_{1} L_{2} D_{1}, L_{1} D_{1} D_{2}$ and $L_{2} D_{1} D_{2}$ and $\mathrm{P}_{4} \times \mathrm{Gm} 1002$ in $\mathrm{L}_{1} \mathrm{~L}_{2} \mathrm{D}_{1}$ and $\mathrm{L}_{2} \mathrm{D}_{1} \mathrm{D}_{2}$ had significant and positive SCA effects. Indicating that these crosses are the best combinations for lateness.

Results in Table 12 refer to $\mathrm{P}_{1} \times \mathrm{Gm} 174$ had highly significant and positively SCA effects in $\mathrm{L}_{1} \mathrm{~L}_{2} \mathrm{D}_{1}$ and $L_{2} D_{1} D_{2}, P_{1} \times G m 1002$ had highly significant and negatively SCA effects in $\mathrm{L}_{2} \mathrm{D}_{1} \mathrm{D}_{2}, \mathrm{P}_{3} \times \mathrm{Gm} 1021$ had highly significant and negative SCA effects in $\mathrm{L}_{1} \mathrm{~L}_{2} \mathrm{D}_{2}$ and $\mathrm{L}_{2} \mathrm{D}_{1} \mathrm{D}_{2} . \mathrm{P}_{5} \times \mathrm{Gm} 174$ had highly significant and negatively SCA effects in $\mathrm{L}_{1} \mathrm{D}_{1} \mathrm{D}_{2} . \mathrm{P}_{7} \times \mathrm{Gm} 174$ had highly significant and negatively SCA effects in $\mathrm{L}_{1} \mathrm{D}_{1} \mathrm{D}_{2} . \mathrm{P}_{9} \times \mathrm{Gm} 174$ had significant and negatively SCA effects in $\mathrm{L}_{1} \mathrm{~L}_{2} \mathrm{D}_{2}$ and $\mathrm{L}_{2}$ $\mathrm{D}_{1} \mathrm{D}_{1}$. It is noticed that most crosses showed significant and highly significant positive SCA effects for plant height, indicating that these crosses are the best combinations for plant height.
Results in Table 12 cleared that crosses refer to $\mathrm{P}_{1} \times \mathrm{Gm} 174$ had significant and negative SCA effects in $\mathrm{L}_{2} \mathrm{D}_{1} \mathrm{D}_{2} ; \mathrm{P}_{1} \times \mathrm{Gm} 1002$ had highly significant and negatively SCA effects in $\mathrm{L}_{1} \mathrm{D}_{1} \mathrm{D}_{2}, \mathrm{P}_{1} \times \mathrm{Gm} 1021$ had highly significant and negatively significant SCA effects in $\mathrm{L}_{1} \mathrm{D}_{1} \mathrm{D}_{2} . \quad \mathrm{P}_{2} \times \mathrm{Gm} 1021$ had highly significant and negatively significant SCA effects in $\mathrm{L}_{1} \mathrm{D}_{1} \mathrm{D}_{2} . \mathrm{P}_{3} \times \mathrm{Gm} 1021$ had highly significant and negative SCA effects in $\mathrm{L}_{1} \mathrm{~L}_{2} \mathrm{D}_{2}$ and $\mathrm{L}_{1} \mathrm{D}_{1} \mathrm{D}_{2} . \mathrm{P}_{5} \times \mathrm{Gm} 174$ had highly significant and negative significant SCA effects in $\mathrm{L}_{1} \mathrm{D}_{1} \mathrm{D}_{2}$. $\mathrm{P}_{7} \times \mathrm{Gm} 174$ had highly significant and negatively SCA effects in $\mathrm{L}_{1} \mathrm{D}_{1} \mathrm{D}_{2} . \mathrm{P}_{8} \times \mathrm{Gm} 1002$ had significant and significantly negative SCA effects in $L_{1} L_{2} D_{2}$ and $L_{1} D_{1} D_{2}$, indicating that these crosses are the best combinations for lower ear height.

Results shown in Table 13 for ear position (\%) show that cross $P_{3} \times$ Gm 1021 had significant and negative SCA effects in $\mathrm{L}_{1} \mathrm{D}_{1} \mathrm{D}_{2}, \mathrm{P}_{8} \times \mathrm{Gm} 1002$ had significant and negatively significant SCA effects in $L_{1} L_{2} D_{1}$ and $L_{1} D_{1} D_{2}$, Indicating that these crosses are the best combinations for lower ear placement.

Results in Table 13 for grain yield showed that crosses $\mathrm{P}_{1} \times \mathrm{Gm} 174$ in $\mathrm{L}_{1} \mathrm{~L}_{2} \mathrm{D}_{1}, \mathrm{~L}_{1} \mathrm{~L}_{2} \mathrm{D}_{2}, \mathrm{~L}_{1} \mathrm{D}_{1} \mathrm{D}_{2}$ and $\mathrm{L}_{2} \mathrm{D}_{1} \mathrm{D}_{2} ; \mathrm{P}_{2} \times \mathrm{Gm} 1002$ in $\mathrm{L}_{1} \mathrm{~L}_{2} \mathrm{D}_{1}, \mathrm{~L}_{1} \mathrm{~L}_{2} \mathrm{D}_{1}$ and $\mathrm{L}_{1} \mathrm{D}_{1} \mathrm{D}_{2}$; $\mathrm{P}_{3} \times \mathrm{Gm}$ in $\mathrm{L}_{1} \mathrm{~L}_{2} \mathrm{D}_{1}, \mathrm{~L}_{1} \mathrm{D}_{1} \mathrm{D}_{2}$ and $\mathrm{L}_{2} \mathrm{D}_{1} \mathrm{D}_{2}$. and $\mathrm{L}_{2} \mathrm{D}_{1} \mathrm{D}_{2}$. $\mathrm{P}_{4} \times \mathrm{Gm} 174$ in $\mathrm{L}_{1} \mathrm{~L}_{2} \mathrm{D}_{2}$ and $\mathrm{L}_{1} \mathrm{D}_{1} \mathrm{D}_{2} ; \mathrm{P}_{5} \times \mathrm{Gm} 174$ in $\mathrm{L}_{1} \mathrm{~L}_{2} \mathrm{D}_{2}$ ; $\mathrm{P}_{5} \times \mathrm{Gm} 1021$ in $\mathrm{L}_{1} \mathrm{~L}_{2} \mathrm{D}_{1} . \mathrm{P}_{6} \times \mathrm{Gm} 1021$ in $\mathrm{L}_{1} \mathrm{~L}_{2} \mathrm{D}_{1}, \mathrm{~L}_{1} \mathrm{~L}_{2} \mathrm{D}_{1}$ , $\mathrm{L}_{1} \mathrm{~L}_{2} \mathrm{D}_{2}, \mathrm{~L}_{1} \mathrm{D}_{1} \mathrm{D}_{2}$ and $\mathrm{L}_{2} \mathrm{D}_{1} \mathrm{D}_{2} ; \mathrm{P}_{7} \times \mathrm{Gm} 1002$ in $\mathrm{L}_{1} \mathrm{~L}_{2} \mathrm{D}_{1}$ 
Sultan, M. S. et al.

and $\mathrm{L}_{1} \mathrm{D}_{1} \mathrm{D}_{2} ; \mathrm{P}_{8} \times \mathrm{Gm} 1002$ in $\mathrm{L}_{1} \mathrm{~L}_{2} \mathrm{D}_{2}$, and $\mathrm{L}_{2} \mathrm{D}_{1} \mathrm{D}_{2}$ and $\mathrm{P}_{9} \times \mathrm{Gm} 1002$ in $\mathrm{L}_{1} \mathrm{~L}_{2} \mathrm{D}_{1}$ had highly significant and significant positive SCA effects. it could be concluded that the parental inbred line for that crosses could made

themselves recombination's. These results are in line with those obtained by Osman and Ibrahim (2007), Singh and Roy (2007) , Parmar (2007) , Liu (2008)and Fan et al.(2009).

Table 11. SCA effects of 27 yellow single crosses of maize at their combined data over two locations and over two density for Days to 50\% tasseling and Days to 50\% silking during growing season 2016.

\begin{tabular}{|c|c|c|c|c|c|c|c|c|}
\hline & \multicolumn{4}{|c|}{ Days to $50 \%$ Tasseling } & \multicolumn{4}{|c|}{ Days to 50\% Silking } \\
\hline & $\mathbf{L}_{1} \mathbf{L}_{2} \mathbf{D}_{1}$ & $\mathbf{L}_{1} \mathbf{L}_{2} \mathbf{D}_{2}$ & $\mathbf{L}_{1} \mathbf{D}_{1} \mathbf{D}_{2}$ & $\mathbf{L}_{2} \mathbf{D}_{1} \mathbf{D}_{2}$ & $\mathbf{L}_{1} \mathbf{L}_{2} \mathbf{D}_{1}$ & $\mathbf{L}_{1} \mathbf{L}_{2} \mathbf{D}_{2}$ & $\mathbf{L}_{1} \mathbf{D}_{1} \mathbf{D}_{2}$ & $\mathbf{L}_{2} \mathbf{D}_{1} \mathbf{D}_{2}$ \\
\hline$\overline{\mathrm{P}_{1} \times \mathrm{Gm} 174}$ & $-1.35^{*}$ & -0.12 & -0.45 & -1.02 & -1.25 & -0.31 & -0.58 & -0.98 \\
\hline $\mathrm{P}_{1} \times \mathrm{Gm} 1002$ & $2.13 * *$ & $1.30 *$ & $1.55 * *$ & $1.88^{*}$ & $2.01 * *$ & 0.99 & $1.10^{*}$ & $1.90 * *$ \\
\hline $\mathrm{P}_{1} \times \mathrm{Gm} 1021$ & -0.78 & $-1.18 *$ & $-1.10^{*}$ & -0.86 & -0.77 & -0.68 & -0.52 & -0.92 \\
\hline $\mathrm{P}_{2} \times \mathrm{Gm} 174$ & 0.65 & 0.54 & 0.33 & 0.86 & 0.70 & 0.64 & 0.36 & 0.97 \\
\hline $\mathrm{P}_{2} \times \mathrm{Gm} 1002$ & -0.70 & -0.53 & -0.51 & -0.73 & -0.54 & -0.57 & -0.45 & -0.66 \\
\hline $\mathrm{P}_{2} \times \mathrm{Gm} 1021$ & 0.06 & -0.01 & 0.18 & -0.14 & -0.15 & -0.07 & 0.09 & -0.31 \\
\hline $\mathrm{P}_{3} \times \mathrm{Gm} 174$ & 0.15 & -0.23 & -0.06 & -0.02 & 0.25 & -0.36 & -0.19 & 0.08 \\
\hline $\mathrm{P}_{3} \times \mathrm{Gm} 1002$ & -0.54 & -0.14 & -0.40 & -0.28 & -0.65 & 0.10 & -0.34 & -0.22 \\
\hline $\mathrm{P}_{3} \times \mathrm{GM} 1021$ & 0.39 & 0.38 & 0.46 & 0.31 & 0.40 & 0.27 & 0.53 & 0.14 \\
\hline $\mathrm{P}_{4} \times \mathrm{Gm} 174$ & -0.63 & -0.29 & -0.23 & -0.69 & -0.97 & -0.14 & -0.19 & -0.92 \\
\hline $\mathrm{P}_{4} \times \mathrm{Gm} 1002$ & $1.35^{*}$ & 0.14 & 0.44 & 1.05 & $1.62 * *$ & -0.01 & 0.33 & $1.28 * *$ \\
\hline $\mathrm{P}_{4} \times \mathrm{Gm} 1021$ & -0.72 & 0.15 & -0.21 & -0.36 & -0.65 & 0.15 & -0.14 & -0.36 \\
\hline $\mathrm{P}_{5} \times \mathrm{Gm} 174$ & -0.80 & -0.57 & -0.84 & -0.52 & -0.91 & -0.48 & -0.69 & -0.70 \\
\hline $\mathrm{P}_{5} \times \mathrm{Gm} 1002$ & 0.52 & 0.52 & 0.99 & 0.05 & 0.35 & 0.49 & 0.66 & 0.17 \\
\hline $\mathrm{P}_{5} \times \mathrm{Gm} 1021$ & 0.28 & 0.04 & -0.15 & 0.48 & 0.57 & -0.01 & 0.03 & 0.52 \\
\hline $\mathrm{P}_{6} \times \mathrm{Gm} 174$ & 0.04 & -0.35 & -0.23 & -0.08 & -0.08 & -0.31 & -0.14 & -0.25 \\
\hline $\mathrm{P}_{6} \times \mathrm{Gm} 1002$ & -0.65 & -0.09 & -0.40 & -0.34 & -0.82 & -0.01 & -0.28 & -0.55 \\
\hline $\mathrm{P}_{6} \times \mathrm{Gm} 1021$ & 0.61 & 0.43 & 0.62 & 0.42 & 0.90 & 0.32 & 0.42 & 0.80 \\
\hline $\mathrm{P}_{7} \times \mathrm{Gm} 174$ & 0.20 & -0.01 & -0.06 & 0.25 & 0.53 & 0.25 & 0.14 & 0.64 \\
\hline $\mathrm{P}_{7} \times \mathrm{Gm} 1002$ & -0.31 & -0.42 & -0.23 & -0.51 & -0.38 & -0.46 & -0.34 & -0.49 \\
\hline $\mathrm{P}_{7} \times \mathrm{Gm} 1021$ & 0.11 & 0.43 & 0.29 & 0.25 & -0.15 & 0.21 & 0.20 & -0.14 \\
\hline $\mathrm{P}_{8} \times \mathrm{Gm} 174$ & 0.70 & 0.38 & 0.83 & 0.25 & 0.86 & 0.25 & 1.03 & 0.08 \\
\hline $\mathrm{P}_{8} \times \mathrm{Gm} 1002$ & -0.81 & -0.03 & -0.51 & -0.34 & -0.88 & 0.04 & -0.28 & -0.55 \\
\hline $\mathrm{P}_{8} \times \mathrm{Gm} 1021$ & 0.11 & -0.35 & -0.32 & 0.09 & 0.01 & -0.29 & -0.75 & 0.47 \\
\hline $\mathrm{P}_{9} \times \mathrm{Gm} 174$ & 1.04 & 0.65 & 0.72 & 0.98 & 0.86 & 0.47 & 0.25 & 1.08 \\
\hline $\mathrm{P}_{9} \times \mathrm{Gm} 1002$ & -0.98 & -0.75 & -0.95 & -0.78 & -0.71 & -0.57 & -0.40 & -0.88 \\
\hline$\underline{\mathrm{P}_{9} \times \mathrm{Gm} 1021}$ & -0.06 & 0.10 & 0.23 & -0.19 & -0.15 & 0.10 & 0.14 & -0.20 \\
\hline 0.05 & 1.352 & 0.98 & 1.078 & 1.097 & 1.293 & 1.019 & 1.0388 & 1.097 \\
\hline 0.01 & 1.777 & 1.288 & 1.416 & 1.442 & 1.700 & 1.339 & 1.365 & 1.442 \\
\hline
\end{tabular}

*, ** significant at 0.05 and 0.01 level of probability , respectively.

Abbreviations: $L_{1}$ location Gemmeiza ; $L_{2}$ location Mallawy; $D_{1}$ density one (30000 plant / fed.) and $D_{2}$ density two (24000 plant / fed.).

Table 12. SCA effects of 27 yellow single crosses of maize at combined over two locations and over two density for plant height $(\mathrm{cm})$ and ear height $(\mathrm{cm})$ during growing season 2016.

\begin{tabular}{|c|c|c|c|c|c|c|c|c|}
\hline & \multicolumn{4}{|c|}{ Plant height (cm) } & \multicolumn{4}{|c|}{ Ear height (cm) } \\
\hline & $\mathbf{L}_{1} \mathbf{L}_{2} \mathbf{D}_{1}$ & $\mathbf{L}_{1} \mathbf{L}_{2} \mathbf{D}_{2}$ & $\mathbf{L}_{1} \mathbf{D}_{1} \mathbf{D}_{2}$ & $\mathbf{L}_{2} \mathbf{D}_{1} \mathbf{D}_{2}$ & $\mathbf{L}_{1} \mathbf{L}_{2} \mathbf{D}_{1}$ & $\mathbf{L}_{1} \mathbf{L}_{2} \mathbf{D}_{2}$ & $\mathbf{L}_{1} \mathbf{D}_{1} \mathbf{D}_{2}$ & $\mathbf{L}_{2} \mathbf{D}_{1} \mathbf{D}_{2}$ \\
\hline$\overline{\mathrm{P}_{1} \times \mathrm{Gm} 174}$ & $12.72 * *$ & 6.84 & $24.22 * *$ & -4.65 & 4.62 & 2.57 & 12.04 & $-4.84 *$ \\
\hline $\mathrm{P}_{1} \times \mathrm{Gm} 1002$ & -3.80 & -7.68 & $-14.47 * *$ & 2.99 & 0.07 & -4.54 & $-6.31 *$ & 1.85 \\
\hline $\mathrm{P}_{1} \times \mathrm{Gm} 1021$ & $-8.93 * *$ & 0.84 & -9.75 & 1.66 & -4.69 & 1.96 & $-5.72 *$ & 2.99 \\
\hline $\mathrm{P}_{2} \times \mathrm{Gm} 174$ & 2.11 & -3.22 & -3.90 & 2.79 & 1.96 & 0.52 & 1.59 & 0.88 \\
\hline $\mathrm{P}_{2} \times \mathrm{Gm} 1002$ & 4.59 & 9.27 & $13.75 * *$ & 0.10 & 2.40 & 3.07 & 4.41 & 1.07 \\
\hline $\mathrm{P}_{2} \times \mathrm{Gm} 1021$ & -6.70 & -6.05 & $-9.86 *$ & -2.90 & -4.36 & -3.59 & -6.00 & -1.95 \\
\hline $\mathrm{P}_{3} \times \mathrm{Gm} 174$ & -3.50 & 9.01 & 2.10 & 3.40 & -0.65 & 1.69 & 0.48 & 0.55 \\
\hline $\mathrm{P}_{3} \times \mathrm{Gm} 1002$ & 5.48 & 4.82 & 8.42 & 1.88 & 4.96 & 6.07 & 9.30 & 1.73 \\
\hline $\mathrm{P}_{3} \times \mathrm{GM} 1021$ & -1.98 & $-13.83 * *$ & $-10.52^{* *}$ & -5.28 & -4.30 & $-7.76 * *$ & $-9.78 * *$ & -2.28 \\
\hline $\mathrm{P}_{4} \times \mathrm{Gm} 174$ & 0.44 & 3.78 & 2.72 & 1.51 & -3.82 & 2.07 & -2.63 & 0.88 \\
\hline $\mathrm{P}_{4} \times \mathrm{Gm} 1002$ & 2.76 & -2.40 & 1.36 & -1.01 & 1.12 & 0.46 & 1.35 & 0.23 \\
\hline $\mathrm{P}_{4} \times \mathrm{Gm} 1021$ & -3.20 & -1.38 & -4.08 & -0.51 & 2.70 & -2.54 & 1.28 & -1.12 \\
\hline $\mathrm{P}_{5} \times \mathrm{Gm} 174$ & -6.22 & -0.66 & $-10.01 * *$ & 3.12 & -5.43 & -5.09 & $-9.85 * *$ & -0.67 \\
\hline $\mathrm{P}_{5} \times \mathrm{Gm} 1002$ & 1.93 & -4.85 & -1.36 & -1.56 & 1.85 & -0.87 & 0.96 & 0.01 \\
\hline $\mathrm{P}_{5} \times \mathrm{Gm} 1021$ & 4.30 & 5.51 & 11.36 & -1.56 & 3.59 & 5.96 & 8.89 & 0.66 \\
\hline $\mathrm{P}_{6} \times \mathrm{Gm} 174$ & 1.94 & 1.34 & 4.77 & -1.49 & 0.68 & 2.30 & 1.54 & 1.44 \\
\hline $\mathrm{P}_{6} \times \mathrm{Gm} 1002$ & -3.24 & -4.51 & -7.75 & -0.01 & -1.21 & -4.15 & $-6.15^{*}$ & 0.79 \\
\hline $\mathrm{P}_{6} \times \mathrm{Gm} 1021$ & 1.30 & 3.17 & 2.98 & 1.49 & 0.53 & 1.85 & 4.61 & -2.23 \\
\hline $\mathrm{P}_{7} \times \mathrm{Gm} 174$ & -4.83 & -7.27 & $-9.95 * *$ & -2.15 & -1.04 & -5.54 & -6.52 & -0.06 \\
\hline $\mathrm{P}_{7} \times \mathrm{Gm} 1002$ & -3.52 & -0.46 & -0.97 & -3.01 & -0.77 & 3.69 & 4.13 & -1.21 \\
\hline $\mathrm{P}_{7} \times \mathrm{Gm} 1021$ & 8.35 & 7.73 & 10.92 & 5.16 & 1.81 & 1.85 & 2.39 & 1.27 \\
\hline $\mathrm{P}_{8} \times \mathrm{Gm} 174$ & -0.83 & 3.12 & 3.72 & -1.43 & 1.18 & 2.19 & 3.48 & -0.12 \\
\hline $\mathrm{P}_{8} \times \mathrm{Gm} 1002$ & -1.69 & -2.23 & -5.30 & 1.38 & $-6.88^{*}$ & -4.43 & $-7.54 * *$ & -3.77 \\
\hline $\mathrm{P}_{8} \times \mathrm{Gm} 1021$ & 2.52 & -0.88 & 1.59 & 0.05 & 5.70 & 2.24 & 4.06 & 3.88 \\
\hline $\mathrm{P}_{9} \times \mathrm{Gm} 174$ & -1.83 & -12.94 & $-13.67 * *$ & -1.10 & 2.51 & -0.70 & -0.13 & 1.94 \\
\hline $\mathrm{P}_{9} \times \mathrm{Gm} 1002$ & -2.52 & 8.04 & 6.31 & -0.78 & -1.54 & 0.69 & -0.15 & -0.71 \\
\hline $\mathrm{P}_{9} \times \mathrm{Gm} 1021$ & 4.35 & 4.90 & 7.36 & 1.88 & -0.97 & 0.02 & 0.28 & -1.23 \\
\hline 0.05 & 7.33 & 12.95 & 8.05 & 10.99 & 5.62 & 6.27 & 5.23 & 4.39 \\
\hline L.S.D. & 9.63 & 17.02 & 10.58 & 14.45 & 7.39 & 8.24 & 6.87 & 5.77 \\
\hline
\end{tabular}

*, ** significant at 0.05 and 0.01 level of probability, respectively.

Abbreviations: $L_{1}$ location Gemmeiza ; $L_{2}$ location Mallawy; $D_{1}$ density one ( 30000 plant / fed.) and $D_{2}$ density two( 24000 plant / fed.). 
Table 13. SCA effects of 27 yellow single crosses of maize at combined data aver two locations and over two density for ear position (\%) and grain yield (ard./fed.) during growing season 2016.

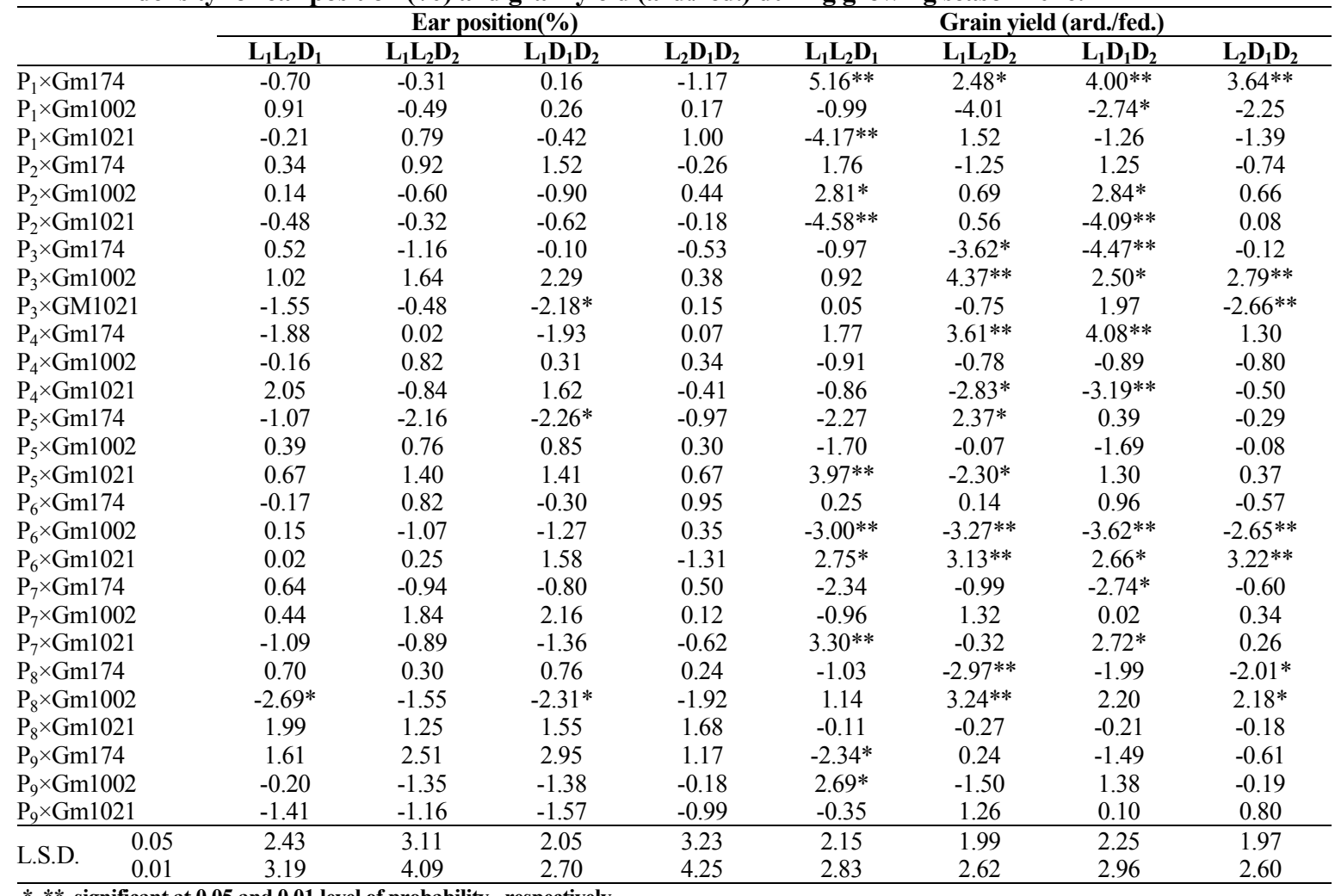

*, ** significant at 0.05 and 0.01 level of probability , respectively.

Abbreviations: $L_{1}$ location Gemmeiza ; $L_{2}$ location Mallawy; $D_{1}$ density one ( 30000 plant / fed.) and $D_{2}$ density two (24000 plant / fed.).

\section{REFERENCES}

Abd El-Aty, M.S. and Y.S. Katta (2002). Estimation of heterosis and combining ability for yield and other agronomic traits in maize hybrids (Zea mays L.). J. Agric. Sci., Mansoura Univ., 27(8): 5137-5146.

Agrobase 21(2001). Agronomix Software, Inc. 171 Waterloo Street Winnipeg, Manitoba, Canada R3N OS4,www. Agronomix.mb.ca

Ceyhan E (2003) Determination of some agricultural characters and their heredity through line $\times$ tester method in pea parents and crosses. Selcuk. Univ. Graduate School Nat Applied Sci. pp 130.

El- Shenawy, A. A., H. E. Mosa and A. A. Motawei. (2009).Combining Ability of crosses and Stability Parameters of their Single Crosses. J. Agri. Res. 35(4).

Kamara, M. M., I. S. El-Degwy and H. Koyama (2014). Estimation of combining ability of some maize inbred lines using line $\times$ tester mating design under two nitrogen levels. AJCS 8(9):1336-1342.

Kempthorne, O., (1957). An introduction to genetic statics. Johan wily and sons, Inc. New York, USA.468-473.

Machado, J. C.; J. C. Souza ; M. A. P. Ramalho and J. L. Lima (2009). Stability of combining ability effects in maize hybrids. Scientia Agricola, 66(4): 494498.
Moosavi, S. G.; M. J. Seghatoleslami and A. Moazeni (2012). Effect of planting date and plant density on morphological traits, LAI and forage corn (Sc. 370) yield in second cultivation. Azad University, Iran Inter. Res. J. of Appl. and Basic Sci. 3 (1): 57-63.

Nawar, A. A.; S. A. El-Shamarka and E. A. El-Absawy (2002). Diallel analysis of some agronomic traits of maize. J. Agric. Sci. Mansoura Univ., 27 (11): 7203-7213.

Osman, M. M. A. and M. H. A. Ibrahim (2007). A study on combining ability of new lines using line $\mathrm{x}$ tester analysis. J. Agric. Sci. Mansoura Univ., 32(2): 815830.

Parmar, H. P. (2007). Combining ability and stability analysis in forage maize (Zea mays L.). Ph. D. Thesis B.A. College of Agric., Gujarat Agric. Univ., Anand campus, India.

Rakesh Kumar ; S. Mohinder and M. S. Narwal (2006). Combining ability analysis for grain yield and its contributing traits in maize (Zea mays L.). National J. of Plant Improvement. , 8 (1) : 62-66.

Singh, P. K. and A. K. Roy (2007). Diallel analysis of inbred lines in maize (Zea mays L.). International J. of Agric. Sci. 3(1): 213-216.

Singh, P. K.(2005). Components of genetic variation in yield traits of maize. Journal of Research, Birsa Agric. Univ. 17( 2): 257-262. 


\section{Sultan, M. S. et al.}

Steel R.G. and J.H. Torrie (1980). Principle and procedures of Statistics. Me. Grow Hill Book. Tne., new York, USA.

Sultan, M.S.; M.A. Abdel-Monaem and Soad H. Haffez (2010). combining ability and heterosis estimates for yield, yield components and quality traits in maize under two plant densities. J. Agric. Sic., Mansoura Univ., 1(10):1419-1430
Surya Prakash and D. K. Ganguli (2004). Combining ability for various yield component characters in maize ( Zea mays L.). Journal of Research, Birsa Agricultural University. , 16(1): 55-60.

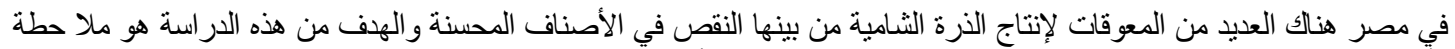

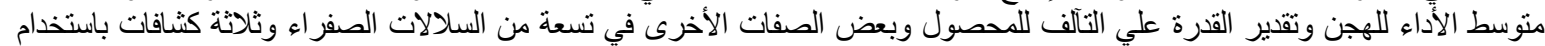

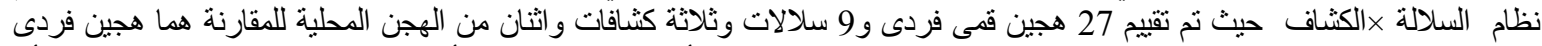

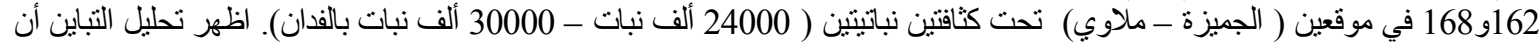
تباين السلالات و الكثافات و الهجن الناتجة كانت عالية المعنوية وذات أهمية كبيرة في التحليل التجميعي تحت الكثافتين و كانت الهجن 174, P6 × ذات معدل إنتاج عالية في محصول الحبوب بالنسبة لمتوسط الأداء. وتأثير القدرة العامة على التآلف كانت السلالات

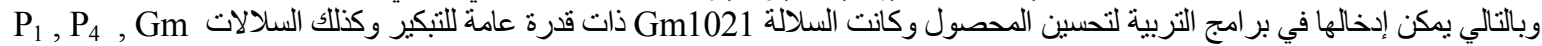

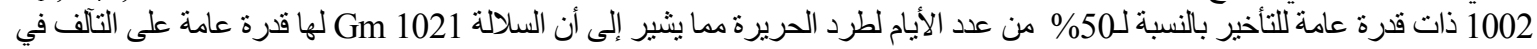
التبكير في النضج وكانت الهجن ,

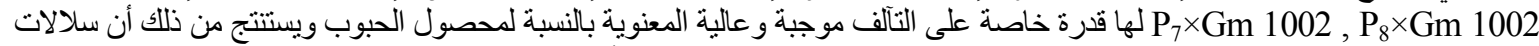

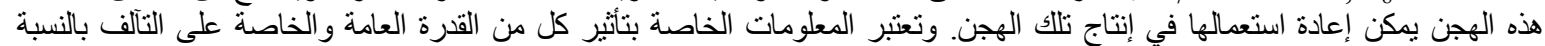

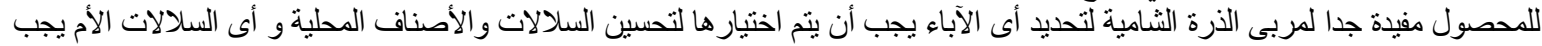
استخدامها في إنتاج الهجن ذات المحصول العالي من الحبوب. 